\title{
Using lakes and rivers for extraction and disposal of heat: Estimate of regional potentials
}

\author{
Adrien Gaudard ${ }^{a}$ \\ ${ }^{\text {a }}$ Eawag, Swiss Federal Institute of Aquatic Science and Technology, Surface Waters - \\ Research and Management, Seestrasse 79, 6047 Kastanienbaum, Switzerland \\ E-mail: adrien.gaudard@eawag.ch

\begin{abstract}
Alfred Wüest ${ }^{a, b}$
${ }^{\text {a }}$ Eawag, Swiss Federal Institute of Aquatic Science and Technology, Surface Waters Research and Management, Seestrasse 79, 6047 Kastanienbaum, Switzerland

${ }^{b}$ Physics of Aquatic Systems Laboratory - Margaretha Kamprad Chair, École Polytechnique Fédérale de Lausanne, Institute of Environmental Engineering, Route Cantonale, 1015 Lausanne, Switzerland

E-mail: alfred.wueest@eawag.ch
\end{abstract}

\author{
Martin Schmid ${ }^{\mathrm{a}}$ \\ ${ }^{a}$ Eawag, Swiss Federal Institute of Aquatic Science and Technology, Surface Waters - \\ Research and Management, Seestrasse 79, 6047 Kastanienbaum, Switzerland \\ E-mail: martin.schmid@eawag.ch
}

Corresponding author: Martin Schmid, martin.schmid@eawag.ch

This document is the accepted manuscript version of the following article: Gaudard, A., Wüest, A., \& Schmid, M. (2018). Using lakes and rivers for extraction and disposal of heat: estimate of regional potentials. Renewable Energy. https:// doi .org/10.1016/j. renene.2018.10.095 


\title{
Using lakes and rivers for extraction and disposal of heat:
}

\section{Estimate of regional potentials}

\author{
Adrien Gaudard ${ }^{\mathrm{a}}$, Alfred Wüest ${ }^{\mathrm{a}, \mathrm{b}}$, Martin Schmid ${ }^{\mathrm{a}}$ \\ ${ }^{a}$ Eawag, Swiss Federal Institute of Aquatic Science and Technology, Surface Waters - Research and \\ Management, Kastanienbaum, Switzerland \\ ${ }^{b}$ Physics of Aquatic Systems Laboratory - Margaretha Kamprad Chair, École Polytechnique Fédérale \\ de Lausanne, Institute of Environmental Engineering, Lausanne, Switzerland
}

\begin{abstract}
There is increasing interest in using waterbodies as renewable energy sources to heat and cool buildings and infrastructure. Here, we estimate the potentials for heat extraction and disposal for the main lakes and rivers of Switzerland based on acceptable temperature changes in the waterbodies, and compare them to regional demands. In most cases, the potentials considerably exceed the demand, and minor impacts on the thermal regime of the waterbodies are expected. There are, however, critical situations: rivers crossing densely-populated areas, where demand often exceeds the potential, and heat disposal in summer into lowland rivers and shallow lakes, where temperatures may exceed ecological criteria. To assess the impacts of a realistic thermal use, we model the temperature effects in two lakes: Upper Lake Constance, a large lake with relatively low population density, and Lower Lake Zurich, a smaller lake with high regional demand. The estimated mean temperature alterations are -0.05 to $+0.02{ }^{\circ} \mathrm{C}$ for Lake Constance, and -0.60 to $+0.22{ }^{\circ} \mathrm{C}$ for Lake Zurich. Based on the model results, we discuss the effects of operating parameters on the efficiency and impacts of thermal use. Our analysis demonstrates that waterbodies provide real alternatives for heat/cold production in many regions of the world.
\end{abstract}

Keywords: surface waters heat management, heat pump systems, free cooling, carbon-free heat production, district cooling and heating, surface waters temperature

\section{Introduction}

Ambient heat, stored in air, ground and waterbodies, can be used for heating and cooling of buildings and infrastructure [1-3]. Such thermal use will expectedly increase in the future [4], for example in the context of district heating [5]. Indeed, this energy resource is renewable, reliable and local, and could significantly reduce the quantities of fossil fuels burnt for heating and of electricity used by air-based chillers for cooling [3]. Thermal use is, however, only feasible close to sources/sinks of heat, as it is difficult to transport heat efficiently. In this paper, we focus on thermal use of lakes and rivers. Most available literature discusses specific case studies (e.g., energy supply for a given system such as in Ref. [6]) or the potential of individual waterbodies (for an overview of such studies in Switzerland, see Appendix E). In Refs. [7,8], heating and cooling systems from surface waters were classified and described together with their main components, summarizing the state of the art; however, the authors note a lack of both guidelines for system design and energy calculation 
procedures. There is a larger body of literature concerning district heating and cooling $[9,10]$, as well as thermal use of ocean coastal waters $[11,12]$ and groundwater $[13,14]$. There are various different applications utilizing similar heat sources/sinks that are available in many regions of the world, such as mine water [15,16], irrigation water reservoirs [17], sediments [18], wastewater [19,20], and shower water [21].

In Switzerland, a large number of lakes and rivers containing considerable reserves of thermal energy [22] are often located near densely populated areas. The thermal regime of lakes and rivers is primarily influenced by atmospheric conditions: they absorb heat from the sun and the air over spring and summer and release it to the atmosphere over winter. As a consequence, the temperature of lake and river water follows air temperature with diurnal and seasonal cycles [23], but with a smaller amplitude and a phase shift. Due to their thermal inertia, large waterbodies are on average warmer than the air in winter and colder in summer, which makes them suitable for both heat extraction and heat disposal in many parts of the world.

River temperatures also strongly depend on the water source and flow properties. Temperatures may occasionally reach extremely high or low values, driven by air temperature and high solar exposure in summer or snowmelt in winter, and aggravated in case of low discharge or slow flow.

Lake temperatures respond to air temperature with a temporal shift dependent on the depth [24]. In spring and summer, the upper layers warm up and a stable stratification develops, and the heat only progressively reaches the deeper layers throughout autumn and early winter. In most mid-latitude lakes, temperature and therefore density are homogenized throughout the water column by vertical mixing in late winter. Vertical mixing supplies oxygen to the deeper layers, which is important for the health of the profundal ecosystem. Lake dynamics is also strongly influenced by wind. In addition to stimulating currents and mixing, wind drags surface water along and can provoke up- and downwelling of significant water masses [25].

When using the thermal energy of these waterbodies, it is important not to alter significantly their thermal regime, so as to avoid to disturb the system.

\section{Thermal use of waterbodies}

\subsection{Overview}

The technology for thermal use of waterbodies typically consists of three main components (Figure 1):

- Water intake and discharge pipes (primary loop), where the intake and discharged water circulate;

- Heat exchangers and a heat transport network (secondary loop);

- Heat pumps and a heating/cooling network (heating/cooling loop).

An alternative design is to use immersed pipes in a closed loop, whereby heat exchange occurs within the waterbody, with no intake of water [2]. 


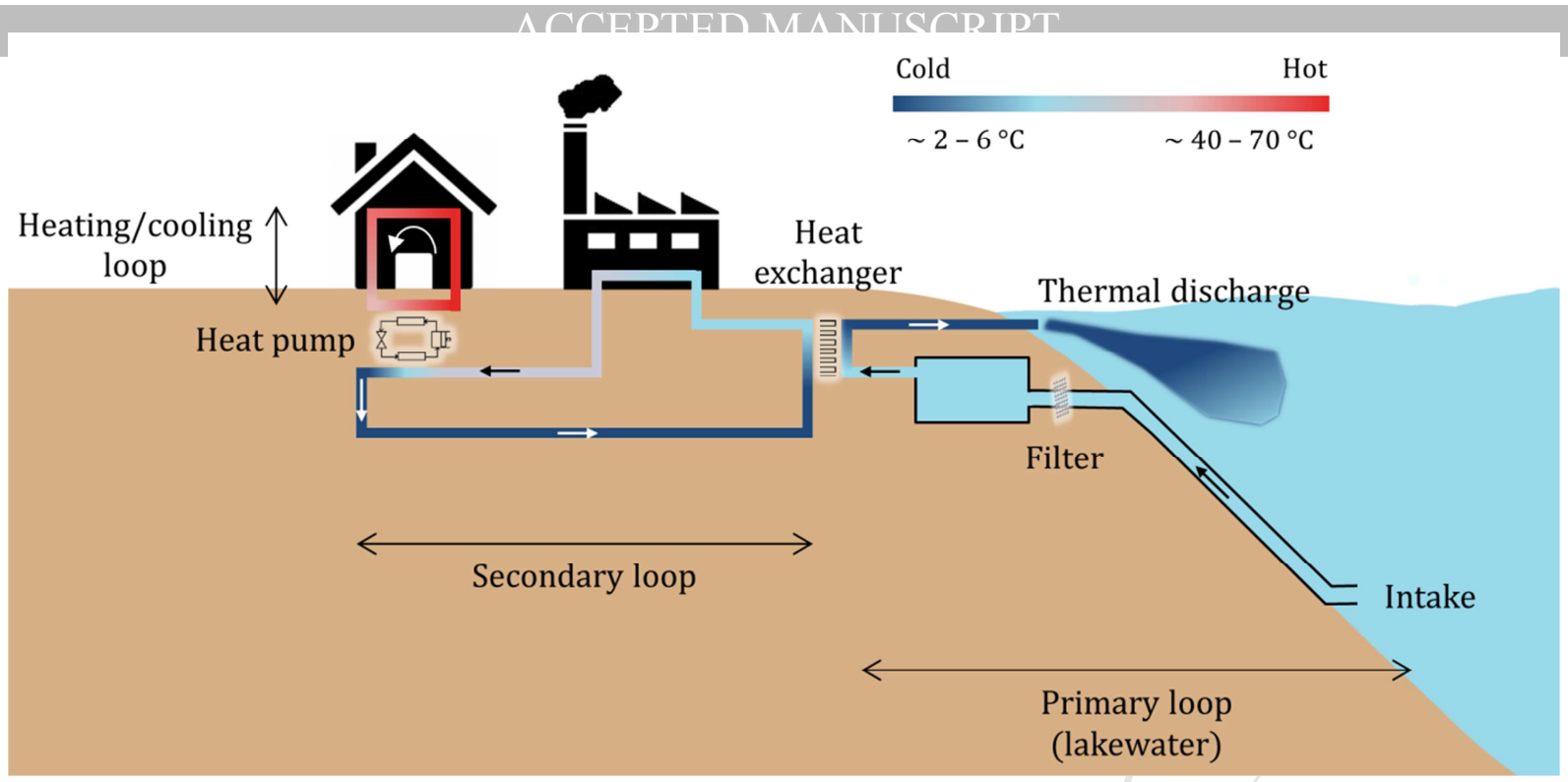

Figure 1 - Example of a thermal use system from a waterbody. In this example, (i) the system provides cooling for an industry and heating for a house, (ii) heating is dominant, so that the discharged water is colder than the intake water, (iii) the source water does not reach the users thanks to a primary heat exchanger.

In the case of heat extraction, heat pumps (Section 2.2) are operated to mechanically extract thermal energy from the source water, or from a heat transport fluid after a primary heat exchange. Thereby, heat pumps transfer heat from a low-temperature source to a high-temperature sink, which can then provide heating for interior spaces, infrastructure or industrial processes.

In the case of heat disposal, cooling of buildings or infrastructure is usually performed by direct circulation of source water, or of a heat transport fluid after a primary heat exchange. Such direct cooling is feasible if the temperature of the source is low enough to satisfy the requirement of the users (e.g., $<15^{\circ} \mathrm{C}$, depending on the design of the cooling infrastructure). In Switzerland, lakes and rivers are generally suitable for air conditioning and process cooling: the deepwater temperature of lakes rarely exceeds $6^{\circ} \mathrm{C}$, and many rivers remain cold throughout the year. In lowland rivers, however, temperatures can rise above $20^{\circ} \mathrm{C}$ during the hottest periods of summer, reducing their capacity for direct cooling.

For processes requiring temperatures lower than that of the waterbody, a chiller (i.e., a heat pump in reverse cycle) must be operated. To satisfy a high cooling demand where water availability is low, advanced cooling techniques should be employed, such as the operation of cooling towers, which enhance cooling by evaporation [26]. These techniques allow cooling with warmer water and recycling of used water [27]: it was estimated that cooling towers can reduce water consumption by a factor of 30 and heat discharged back to the waterbody by a factor of 100 compared to direct cooling [28].

Even though the technical knowledge is well established, thermal use of waterbodies is still limited $[22,29,30]$. Most existing systems were designed more than 30 years ago to cool thermal power plants using river water [31], often with a high temperature difference between intake and discharged water [27]. Since then, few large systems were realized. However, with increasing pressure towards reduction of $\mathrm{CO}_{2}$ emissions, there is growing interest in the vast potential offered by waterbodies for heating and cooling throughout the world [32]. The use of ambient heat could in addition help stabilizing the electricity market, absorbing excess electricity in times of low demand to 
produce heat or cold [5]. This is desirable in the context of increasing shares of renewable electricity. The major ecological drawback of such thermal use is the potential impact on the ecosystems in the affected waterbodies (Section 2.3).

\subsection{Heat pumps}

For heating, the properties of the heat pumps largely determine the electrical needs, working temperatures, operating conditions and thus reliability and overall energetic efficiency of the system. Conventional heat pumps have been known for long and have been thoroughly described $[33,34,4,35]$. The operation of heat pumps requires an input of external energy (usually electricity), which comprises compressor energy, pressure losses in the evaporator and condenser, and energy for system regulation [34].

The coefficient of performance $(C O P)$ of a heat pump measures the ratio between the useful (output) heat $E_{\text {output }}[\mathrm{J}]$ and the required (input) energy $E_{\text {input }}[\mathrm{J}]$. For example, a heat pump with a $C O P$ value of 5 produces 5 units of useful heat out of 4 units of ambient heat and 1 unit of input energy. The $C O P$ can be formulated as [33]:

$$
C O P=\frac{E_{\text {output }}}{E_{\text {input }}} \cong \eta \frac{T_{\mathrm{o}}+273.15}{T_{\mathrm{o}}-T_{\mathrm{s}}}=\eta C O P_{\text {ideal }}
$$

where $T_{\mathrm{o}}\left[{ }^{\circ} \mathrm{C}\right]$ is the temperature of the heat sink (output temperature), $T_{\mathrm{S}}\left[{ }^{\circ} \mathrm{C}\right]$ is the temperature of the heat source, $\eta[-]$ is the efficiency grade, and $C O P_{\text {ideal }}$ is the maximum theoretical value for the COP based on the thermodynamic cycle with given $T_{\mathrm{o}}$ and $T_{\mathrm{S}}$. For thermal use of waterbodies, the COP ranges typically from 3 to $5[36,37]$. Heat pumps are more efficient when operated with a higher source temperature and/or lower output temperature.

Lakes and rivers are a source of low-temperature heat. Because of thermodynamic principles, heat pumps cannot efficiently generate high-temperature heat from such a source: the output working temperature is limited to about 60 to $70^{\circ} \mathrm{C}$, especially in winter and early spring when lakes and rivers are the coldest. This is usually enough to cover domestic room and water heating demand, as well as part of the heat for processes requiring higher temperatures - the remainder is typically obtained by burning fuels.

In this work, we assume $T_{\mathrm{o}}=50^{\circ} \mathrm{C}$ and a $1{ }^{\circ} \mathrm{C}$ loss due to the heat exchangers (i.e., $T_{\mathrm{S}}$ is $1^{\circ} \mathrm{C}$ colder than the source water). Indicative values of the efficiency grade for the three typical natural heat sources, from heat source to heat distribution system, are given in Ref. [33]: $\eta=0.50$ (waterbodies), $\eta=0.45$ (ground), $\eta=0.35$ (ambient air). In practice, waterbodies were indeed often shown to be a more efficient source of heating and cooling than ambient air $[6,38,39]$.

\subsection{Thermal discharge and related impacts}

Water used for heating or cooling purposes is discharged at an altered temperature: it is a thermal discharge. The discharged water is colder (if used for heating) or warmer (if used for cooling) than the intake water. Thermal discharge generally takes place in the same waterbody that serves as water source. The impacts of thermal discharge on the physical properties and subsequently on the ecology of lakes and rivers have been previously reviewed [40] and are only shortly summarized here. On the one hand, thermal discharge modifies the temperature in the receiving waterbody. In general, the resulting ecological impacts are larger if thermal discharge causes alterations exceeding 
or approaching the limits of natural variability (e.g., an increase of surface temperatures in summer). On the other hand, transfer of water to a different location or to a different waterbody may also have impacts. Indeed, such translocation may cause unwanted fluxes of nutrients, oxygen or other compounds [41]. In a stratified lake, if large amounts of water are used and discharged elsewhere, a vertical displacement of the thermocline may occur $[42,43]$. For example, if water is withdrawn from the hypolimnion and discharged into the epilimnion or into a river, the thermocline will gradually sink over the stratified season as water gets translocated. Such displacement should be limited to avoid temperature deviations exceeding natural variability within the lake. Operating with a higher temperature difference between intake and discharged water allows reducing the total water demand and thus thermocline displacement while improving efficiency. This operating design may however increase the local impacts of thermal discharge [42].

In lakes, local impacts (in the vicinity of a thermal discharge) are generally more noticeable than any large-scale change. Local impacts may involve measurable temperature alterations, modified water currents, attraction of or avoidance by mobile organisms, and advancement or retardation of biological cycles [42].

In the case of a thermal use modifying significantly the temperature of large parts of a lake, impacts can occur over broader scales. These may involve change of the heat content of the lake, alteration of the natural stratification (and possibly impact on vertical mixing) and ecological changes such as modified timing and intensity of algal growth or changes in community composition [42].

In rivers, the impacts of a thermal discharge may potentially be felt over long distances (up to hundreds of kilometers), as the temperature alterations are transported by the flow. In the case of important alterations, there can be consequences for aquatic organisms: favorable conditions for better-adapted species, modified timing of some ecological processes or difficulty to spawn or migrate for some fish species [31,42].

A thermal discharge in a river may modify its density before it reaches a downstream lake or ocean $[31,44]$. In such a case, the river may enter the lake or ocean at a different depth, possibly modifying the distribution of sediments, nutrients and oxygen [42]. A relevant fraction of thermal discharge into a lake can be transferred to the outflow in systems with a short residence time and especially under wind influence (e.g., Lake Biel and the Aare [44]).

\section{Scope of this work}

We consider the main lakes, rivers and lake outlets in Switzerland. We estimate the potential for heat extraction and heat disposal of each lake - split into basins if needed - and each river - split into stretches if needed. In addition, we estimate the potential for heat disposal of each lake outlet, assuming intake of cold water from the lake and discharge into the outlet. To compute these potentials, we consider realistic thermal use conditions, as well as the specific properties of each waterbody and seasonal factors, in order to minimize the possible negative impacts on the aquatic system. We further estimate the population living around each waterbody and thereby the regional demand for heating and cooling, which can be compared to the potentials.

We then use a hydrodynamic model to perform the reverse calculation and estimate the thermal impact for a realistic thermal use on a lake. With this model, we investigate the influence of different operating parameters on the operation of thermal use and on the impacts of the associated thermal 
discharge. Finally, we discuss the practical implementation and limitations of thermal use, including planning, operation and impact mitigation.

Previous studies investigated the potential of specific waterbodies (summarized in Appendix E). The present work aims at (i) giving an integrated overview of the potentials in Switzerland, (ii) relating them to the regional demand, (iii) giving insights into the planning of a realistic thermal use, and (iv) providing methods for similar work in other regions of the world. Apart from a recent study in Denmark [45] and to our best knowledge, there is no published estimate of the thermal potential of lakes and rivers and the corresponding demand at the waterbody resolution and for entire countries. In our study, we take specific properties of the waterbodies into account, allowing for a more accurate estimate than previous published work.

\section{Methods}

\subsection{Demand}

We first estimate the overall demand for heating and cooling in Switzerland, and subsequently the average demand per capita. Secondly, we estimate the number of inhabitants living near each considered waterbody via a GIS approach, by summing the inhabitants of all the communes around the lake, along the river stretch, or of the city where the lake outlet is located [46]. Communes of neighboring countries were also included, except those downstream of Switzerland's border. Finally, knowing the demand per capita, we deduce the regional demand for each waterbody.

This method gives an upper estimate of the actual regional demand for thermal use. It is unrealistic to assume that all inhabitants in a commune would be provided with heating and cooling from a waterbody. There are often other local sources of heat (e.g., waste incineration) that can be utilized, and communes sometimes cover large areas or elevation differences that are impractical for distance heating or cooling. Furthermore, the communes near several waterbodies of different type (lake, river or a lake outlet) may be counted more than once. The communes allocated to each waterbody are listed in the data files provided in Appendix A.

Heating and cooling demands strongly depend on local temperatures, which are largely determined by elevation. Here, we assume that the average person in Switzerland lives at $500 \mathrm{~m}$ a.s.l., and that the average demand per capita corresponds to this elevation. Based on observational data, we then make the following simplifying assumptions: heating demand increases linearly with elevation, reaching the double at $1800 \mathrm{~m}$ a.s.l.; cooling demand decreases linearly with elevation, reaching zero at $1500 \mathrm{~m}$ a.s.l. These corrections are based on the elevations of the lake water surfaces and the river gauge stations. 


\subsubsection{Lakes}

222 We perform a potential estimate for all Swiss lakes deeper than 30 meters and with a volume larger than 20 million $\mathrm{m}^{3}$, excluding high alpine reservoirs (see Appendix A for a map and the properties of the considered lakes). The yearly quantity of heat $E_{\text {lake }}[\mathrm{J}]$ that can potentially be extracted from or disposed to a given lake is estimated as:

$$
E_{\text {lake }}=\left\{\begin{array}{cl}
c_{\mathrm{p}} \rho \Delta T_{\text {heat }} V_{\text {mix }} \frac{C O P}{C O P-1} & \text { for heat extraction } \\
c_{\mathrm{p}} \rho \Delta T_{\text {cool }} V_{\text {mix }} & \text { for heat disposal }
\end{array}\right.
$$

where $c_{\mathrm{p}}=4200 \mathrm{~J} \mathrm{~kg}^{-1}{ }^{\circ} \mathrm{C}^{-1}$ is the heat capacity of water, $\rho=1000 \mathrm{~kg} \mathrm{~m}^{-3}$ is the density of water, $V_{\text {mix }}\left[\mathrm{m}^{3}\right]$ is the volume into which the discharged water is expected to mix, and $\Delta T_{\text {heat }}\left[{ }^{\circ} \mathrm{C}\right]$ and $\Delta T_{\text {cool }}\left[{ }^{\circ} \mathrm{C}\right]$ are the allocated temperature differences within $V_{\text {mix }}$ for heat extraction and disposal, respectively.

It was often shown that anthropogenic warming is ecologically more critical than cooling, especially in the context of climate change [42]. For this reason, we set the temperature differences as follows: $\Delta T_{\text {heat }}=0.5^{\circ} \mathrm{C}$ and $\Delta T_{\text {cool }}=1.0^{\circ} \mathrm{C}$. One should note that such temperature alterations may not be acceptable for all lakes, depending on local conditions and ecosystems.

For thermal use in winter, $V_{\text {mix }}$ is considered to be the whole lake. In summer however, $V_{\text {mix }}$ depends on the stratification of the water column and on the depth of the thermal discharge. In oligomictic lakes, $V_{\mathrm{mix}}$ is chosen to avoid a possible disruption of vertical mixing (i.e., neither warming of the epilimnion nor cooling of the hypolimnion). In addition, warming of the surface layers is avoided in spring and summer, as climate change will expectedly have a particularly strong impact there [47].

To estimate the potentials, we assume that water is withdrawn at the most favorable depth, that is where it is the warmest for heat extraction and the coldest for heat disposal. We further assume operation with a maximal temperature difference between intake and discharged water of $10{ }^{\circ} \mathrm{C}$, and that the discharge temperature may not be lower than $2{ }^{\circ} \mathrm{C}$ (for heat extraction) or higher than $15^{\circ} \mathrm{C}$ (for heat disposal). We also estimate the volume of water required to realize the potentials, and the corresponding possible thermocline displacement. 
Based on available discharge- and temperature-monitoring stations, and aiming at covering most of the river flow in Switzerland, locations were selected along rivers with an average discharge larger than $1 \mathrm{~m}^{3} \mathrm{~s}^{-1}$ (see Appendix A for a map and the properties of the considered rivers). The yearly quantity of heat $E_{\text {river }}[\mathrm{J}]$ that can be extracted from or disposed to a given river section is estimated as:

$$
E_{\text {river }}=\left\{\begin{array}{cl}
c_{\mathrm{p}} \rho \Delta T_{\text {heat }} Q_{\text {use }} \Delta t_{\mathrm{op}} \frac{C O P}{C O P-1} & \text { for heat extraction } \\
c_{\mathrm{p}} \rho \Delta T_{\text {cool }} Q_{\text {use }} \Delta t_{\mathrm{op}} & \text { for heat disposal }
\end{array}\right.
$$

where $\Delta T_{\text {heat }}\left[{ }^{\circ} \mathrm{C}\right]$ and $\Delta T_{\text {cool }}\left[{ }^{\circ} \mathrm{C}\right]$ are the allocated temperature differences for heat extraction and disposal, respectively, $Q_{\mathrm{use}}\left[\mathrm{m}^{3} \mathrm{~s}^{-1}\right]$ is the flowrate for thermal use at this location and $\Delta t_{\mathrm{op}}[\mathrm{s}]$ is the duration of an operating season.

We assume operation with a maximal temperature difference $\left(\Delta T_{\text {heat }}\right.$ or $\left.\Delta T_{\text {cool }}\right)$ between intake and discharged water of $10^{\circ} \mathrm{C}$. We choose $Q_{\text {use }}$ so that the temperature alteration in the river before and after thermal use does not exceed the legal limit of $1.5^{\circ} \mathrm{C}$ (valid in Switzerland for rivers in the trout region). We further assume that the discharge temperature may not be lower than $1{ }^{\circ} \mathrm{C}$ (for heat extraction) or higher than $30^{\circ} \mathrm{C}$ (for heat disposal). This allows to identify rivers that are too cold in winter for heat extraction, that is with a winter temperature below or near $2{ }^{\circ} \mathrm{C}$ (these are generally rivers with high alpine catchments). We also estimate the volume of water required to realize the potentials.

Along the course of a river, upstream thermal use can reduce the potential for downstream thermal use by modifying the river temperature. Here, we neglect exchange with the atmosphere, through which the temperature of a river could return towards equilibrium [48] and thereby recover part or all of its thermal potential. The water may therefore not be used more than once. The most upstream location can use the potential corresponding to the entire flowrate of the river. Downstream locations can only use the additional flow, (i.e., the difference between the local flowrate and the flowrate at the previous upstream location). The downstream locations are chosen in river stretches relevant for thermal use, that is, with sufficient additional flow and enough potential users downstream of the previous upstream location.

\subsubsection{Lake outlets}

Large lakes often have a single, large outlet. Their potential for thermal use is further increased if water is also discharged into the outlet (not only into the lake). This is especially interesting in summer, as deep, cold water from the lake can be used for cooling and discharged at a similar or lower temperature than that of the outlet. This brings two main benefits: further warming of the lake is avoided, and the outlet can even be slightly cooled by the thermal discharge in summer. As the temperature alteration resulting from such operation is opposite to the one of the usual method (where water is taken and discharged in the same waterbody), the potential of lake outlets can be added to the potential of lakes and rivers. This approach could also be used for heat extraction in winter from inversely-stratified lakes (typically at higher elevations). 
As for rivers (Section 4.2.2), the yearly quantity of heat that can be disposed to a given lake outlet $E_{\text {lake outlet }}[\mathrm{J}]$ is estimated as:

$$
E_{\text {lake outlet }}=c_{p} \rho \Delta T Q_{\mathrm{use}} \Delta t_{\mathrm{op}} \quad \text { for heat disposal }
$$

where $\Delta T\left[{ }^{\circ} \mathrm{C}\right.$ ] is the temperature difference between the intake lake water and the lake outlet, $Q_{\text {use }}\left[\mathrm{m}^{3} \mathrm{~s}^{-1}\right]$ is the flowrate displaced to the lake outlet and $\Delta t_{\mathrm{op}}[\mathrm{s}]$ is the duration of an operating season. Both $\Delta T$ and $Q_{\text {use }}$ may strongly vary seasonally.

Withdrawing lake water from the hypolimnion in summer and discharging it in the outlet causes a drawdown of the thermocline (Section 2.3). The magnitude of this drawdown is directly proportional to $Q_{\text {use }}$. Here, we choose to limit $Q_{\text {use }}$ so that the drawdown of the thermocline occurring from spring to autumn as a result of thermal use does not exceed $2 \mathrm{~m}$. In winter, when lakes are weakly stratified (and $\Delta T$ is low), $Q_{\text {use }}$ is limited so that the theoretical drawdown of the lake surface would not exceed $2 \mathrm{~m}$ (considering the lake as a closed system).

\subsection{Modeling thermal use}

We use the one-dimensional numerical model Simstrat v1.6 (initially described by Ref. [49], now available at https://github.com/Eawag-AppliedSystemAnalysis/Simstrat/releases/tag/V1.6), applied to Upper Lake Constance over 32 years (1984 to 2015) and to Lower Lake Zurich over 33 years (1981 to 2013), to model thermal discharge. Upper Lake Constance is the second-largest lake of Switzerland, but its shore and surroundings are comparably weakly populated. On the other hand, Lower Lake Zurich lies in a very densely populated area, while its volume is about 14 times smaller than that of Lake Constance. Details about the model set-up are given in Appendix C.

Thermal use is calculated with an average heating and cooling power equal to half the demand estimated for the corresponding lake (Appendix A and Table 1). This thermal use can be considered very intense in Lower Lake Zurich, and moderate in Upper Lake Constance. In order to represent the strong seasonal variability of the demand due to the local weather, the power is scaled at the daily scale using heating and cooling degree-days data from the MeteoSwiss weather stations in Güttingen (for Upper Lake Constance) and Wädenswil (for Lower Lake Zurich). The resulting heat extraction and disposal used in the model are shown in Figure 2. This fine seasonal scaling is a key difference with the work of Ref. [22]. One weakness of this method is the fact that when cooling degree-days are zero (often from October to April), heat disposal is also set to zero. In reality, some users also require cooling throughout winter (e.g., food services, computer systems or laboratories). Our approach tends to underestimate cooling demand, and thus warming of the lakes, in winter, and overestimate them in summer. 


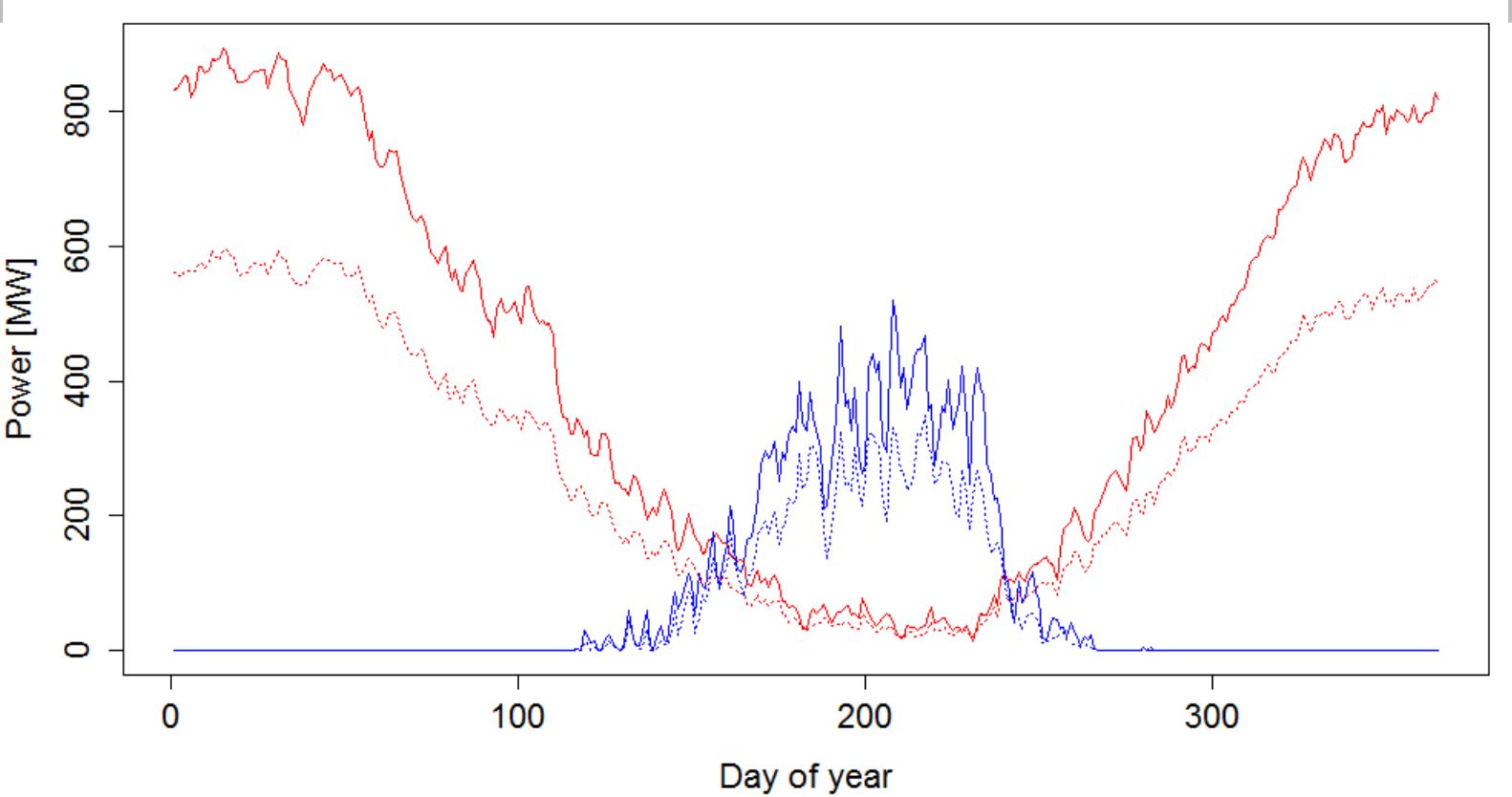

Figure 2 - Heat extraction (red) and disposal (blue) in Upper Lake Constance (dotted line) and Lower Lake Zurich (full line), averaged for each day of year in the simulation period. In Upper Lake Constance ( 200'000 people), average heat extraction / disposal is 293 / $56 \mathrm{MW}$. In Lower Lake Zurich ( 300'000 people), average heat extraction / disposal is 431 / $80 \mathrm{MW}$.

Using the model, we investigate the effects of specific design and operating parameters on the impacts of thermal discharge. Table 1 shows these operation and design parameters, four of which are variable. Table 1 also defines a "baseline" parameter set by giving baseline values for each variable parameter.

Table 1 - Parameters of thermal use. LC: Upper Lake Constance, LZ: Lower Lake Zurich.

\begin{tabular}{|c|c|c|c|}
\hline Category & Parameter & Value or range & Description \\
\hline \multirow{2}{*}{ Design } & $Z_{\text {in }}$ & 10 to $100 \mathrm{~m}$ & Intake depth; baseline value: $20 \mathrm{~m}$. \\
\hline & $z_{\text {out }}$ & 10 to $100 \mathrm{~m}$ & Discharge depth; baseline value: $20 \mathrm{~m}$. \\
\hline \multirow[t]{2}{*}{ Demand } & - & $200^{\prime} 000$ (LC) & Indicative number of inhabitants considered. \\
\hline & & $300^{\prime} 000$ (LZ) & \\
\hline \multirow{4}{*}{$\begin{array}{l}\text { Heat } \\
\text { extraction }\end{array}$} & $P_{\text {heat }}$ & $\begin{array}{l}293 \mathrm{MW}(\mathrm{LC}) \\
431 \mathrm{MW}(\mathrm{LZ})\end{array}$ & Annual average heat extraction from the lake. ${ }^{(1)}$ \\
\hline & $T_{\min }$ & 1 to $5^{\circ} \mathrm{C}$ & $\begin{array}{l}\text { Minimum discharge temperature after heat } \\
\text { extraction; baseline value: } 2^{\circ} \mathrm{C} \text {. }\end{array}$ \\
\hline & $\Delta T_{\text {heat,max }}^{\text {op }}$ & $-10^{\circ} \mathrm{C}$ & $\begin{array}{l}\text { Maximum absolute temperature decrease (between } \\
\text { discharge and intake) after heat extraction. }\end{array}$ \\
\hline & $T_{\mathrm{o}}$ & $60^{\circ} \mathrm{C}$ & Output temperature (heat pumps). \\
\hline \multirow{3}{*}{$\begin{array}{l}\text { Heat } \\
\text { disposal }\end{array}$} & $P_{\text {cool }}$ & $\begin{array}{l}56 \mathrm{MW}(\mathrm{LC}) \\
80 \mathrm{MW}(\mathrm{LZ})\end{array}$ & Annual average heat disposal to the lake. ${ }^{(1)}$ \\
\hline & $T_{\max }$ & 10 to $20^{\circ} \mathrm{C}$ & $\begin{array}{l}\text { Maximum discharge temperature after heat } \\
\text { disposal; baseline value: } 15^{\circ} \mathrm{C} \text {. }\end{array}$ \\
\hline & $\Delta T_{\text {cool,max }}^{\text {op }}$ & $10^{\circ} \mathrm{C}$ & $\begin{array}{l}\text { Maximum absolute temperature increase (between } \\
\text { discharge and intake) after heat disposal. }\end{array}$ \\
\hline
\end{tabular}

${ }^{(1)}$ Values correspond to half the regional demand (listed in the data files provided in Appendix A).

For a given parameter set, we compute the thermal use over the simulation period: intake and discharge temperatures, operating flowrate, final heat extraction and disposal and $C O P$ value (for 
heating). We then feed the resulting thermal discharge to the model. The results of the simulations including thermal use are then compared to those of the reference case (no thermal discharge). This methodology allows for a more accurate simulation of the impacts of thermal discharge on the temperature regime of the lake than the basic estimates using discharge volumes and maximum acceptable temperature alterations. The model also allows investigating the role of different operating parameters relevant to thermal use.

\section{Results}

\subsection{Demand}

Estimates for the current demand for heating and cooling in Switzerland are summarized in Table 2.

Table 2 - Yearly demand for heating (average 2010 to 2014) and for cooling in Switzerland ( 8 million people). Heating estimates from Ref. [50], cooling estimates from Ref. [51].

\begin{tabular}{|c|c|c|c|c|c|}
\hline & $\begin{array}{l}\text { Households } \\
{\left[\mathrm{PJ} \mathrm{yr}^{-1}\right]}\end{array}$ & $\begin{array}{l}\text { Services and } \\
\text { agriculture } \\
{\left[\mathrm{PJ} \mathrm{yr}^{-1}\right]}\end{array}$ & $\begin{array}{l}\text { Industry } \\
{\left[\mathrm{PJ} \mathrm{yr}^{-1}\right]}\end{array}$ & $\begin{array}{c}\text { Total } \\
{\left[\mathrm{PJ} \mathrm{yr}{ }^{-1}\right]}\end{array}$ & $\begin{array}{l}\text { Fossil + } \\
\text { electricity } \\
\text { share }\end{array}$ \\
\hline Room heating & 165.3 & 70.1 & 18.1 & 253.5 & $85 \%$ \\
\hline Water heating & 31.9 & 10.1 & 3.1 & 45.1 & $90 \%$ \\
\hline Process heating & $5.5^{(1)}$ & 2.3 & 87.9 & 95.7 & $90 \%^{(2)}$ \\
\hline Total heating & 202.7 & 82.5 & 109.1 & 394.3 & \\
\hline Air conditioning $^{(3)}$ & 0.1 & 11.4 & 1.0 & 12.5 & $100 \%$ \\
\hline Process cooling ${ }^{(3)(4)}$ & 13.5 & 22.3 & 14.0 & 49.7 & $75 \%$ \\
\hline Total cooling & 13.6 & 33.7 & 15.0 & 62.3 & \\
\hline
\end{tabular}

${ }^{(1)}$ Assuming the same distribution of energy sources between the sectors in 2014 as on average for 2010-2014.

${ }^{(2)}$ Assuming the same distribution of energy sources for process heating as for room and water heating.

(3) Available values are for the electricity consumption related to cooling. It is assumed that all cooling is performed by electrical chillers with an average coefficient of performance of 3 . The actual amount of cold production is equal to the electricity consumption multiplied by 3 .

(4) Demand for cooling excludes the nuclear power plants (which represent $\sim 50 \mathrm{PJ} \mathrm{yr}^{-1}$ [43]), freezing devices and deepfreeze facilities.

From Table 2, the yearly demand per capita can be calculated: 49 GJ for heating and $7.8 \mathrm{GJ}$ for cooling. These values are used in the next sections to estimate the regional demand near specific waterbodies.

In the future, demand for heating and cooling in Switzerland is expected to evolve due to different factors, including demography, change of habits and policies, climate change and evolution of the technology. A projection of the effect of some of these determining factors on the evolution of the demand for heating and cooling is summarized in Table 3. 

in comfort needs, political will, economic development and tourism were not considered.

\begin{tabular}{|c|c|c|c|}
\hline Drivers & $\begin{array}{l}\text { Change in } \\
\text { heating demand }\end{array}$ & $\begin{array}{l}\text { Change in } \\
\text { cooling demand }\end{array}$ & $\begin{array}{l}\text { Considered } \\
\text { period }\end{array}$ \\
\hline Society: increase in population [52] & $+1.0 \% \mathrm{yr}^{-1}$ & $+1.0 \% \mathrm{yr}^{-1}$ & $2015-2045$ \\
\hline Climate: global warming $[53,54]^{(1)}$ & $-0.3 \% \mathrm{yr}^{-1}$ & $+2.3 \% \mathrm{yr}^{-1}$ & $2000-2035$ \\
\hline $\begin{array}{l}\text { Technology: better isolation and } \\
\text { higher efficiency [55] }]^{(2)}\end{array}$ & $-1.3 \% \mathrm{yr}^{-1}$ & $-1.3 \% \mathrm{yr}^{-1}$ & $2000-2015$ \\
\hline Total & $-0.6 \% \mathrm{yr}^{-1}$ & $+2.0 \% \mathrm{yr}^{-1}$ & \\
\hline
\end{tabular}

\subsection{Potential}

\subsubsection{Lakes}

The potentials and demands for the 36 considered lakes or basins (see Appendices A and B) are displayed in Figure 3. Related to the lake volume and surface area, the ranges of the potentials for heat extraction are 3.3-5.8 $\mathrm{PJ} \mathrm{yr}^{-1} \mathrm{~km}^{-3}$ and 0.07-0.98 $\mathrm{PJ} \mathrm{yr}^{-1} \mathrm{~km}^{-2}$, and for heat disposal 1.0-2.4 $\mathrm{PJ} \mathrm{yr}^{-}$ ${ }^{1} \mathrm{~km}^{-3}$ and $0.014-0.40 \mathrm{PJ} \mathrm{yr}^{-1} \mathrm{~km}^{-2}$ (Figure 4). The geographical distributions of these potentials and demands are shown in Figure 7 (heat extraction) and Figure 8 (heat disposal).

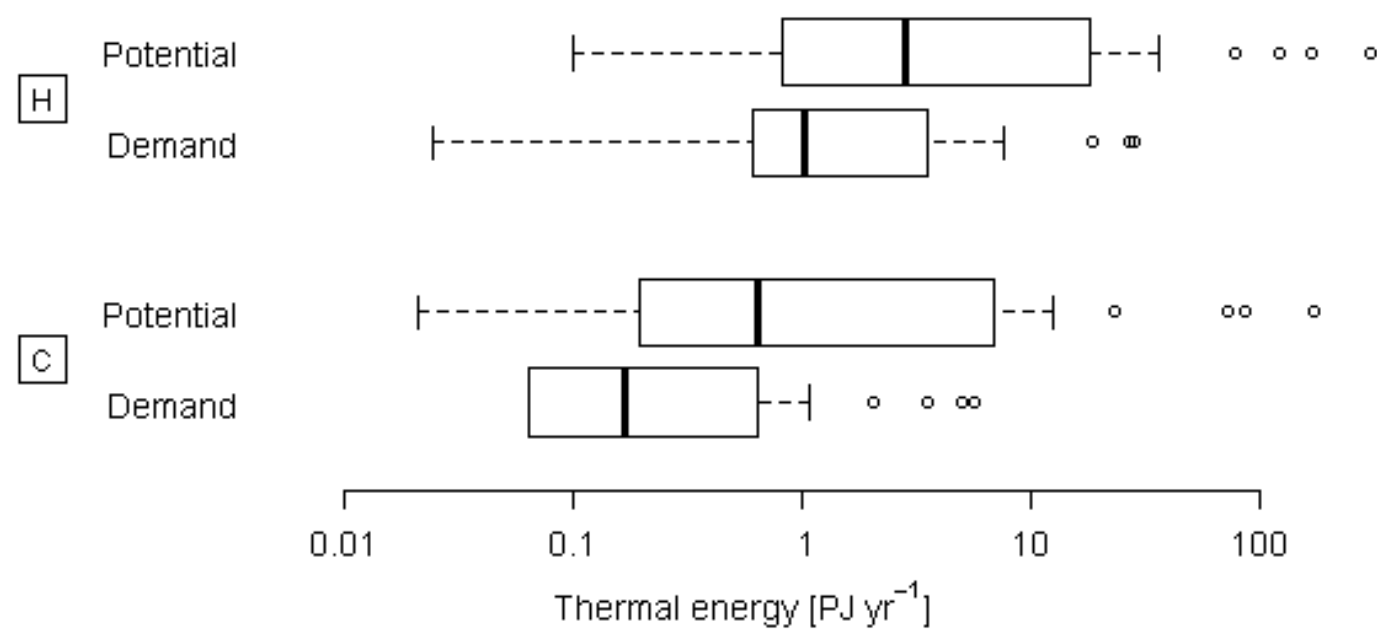
$\mathrm{H}$ : heat extraction, C: heat disposal. The boxes show the $1^{\text {st }}, 2^{\text {nd }}$ and $3^{\text {rd }}$ quartiles. 


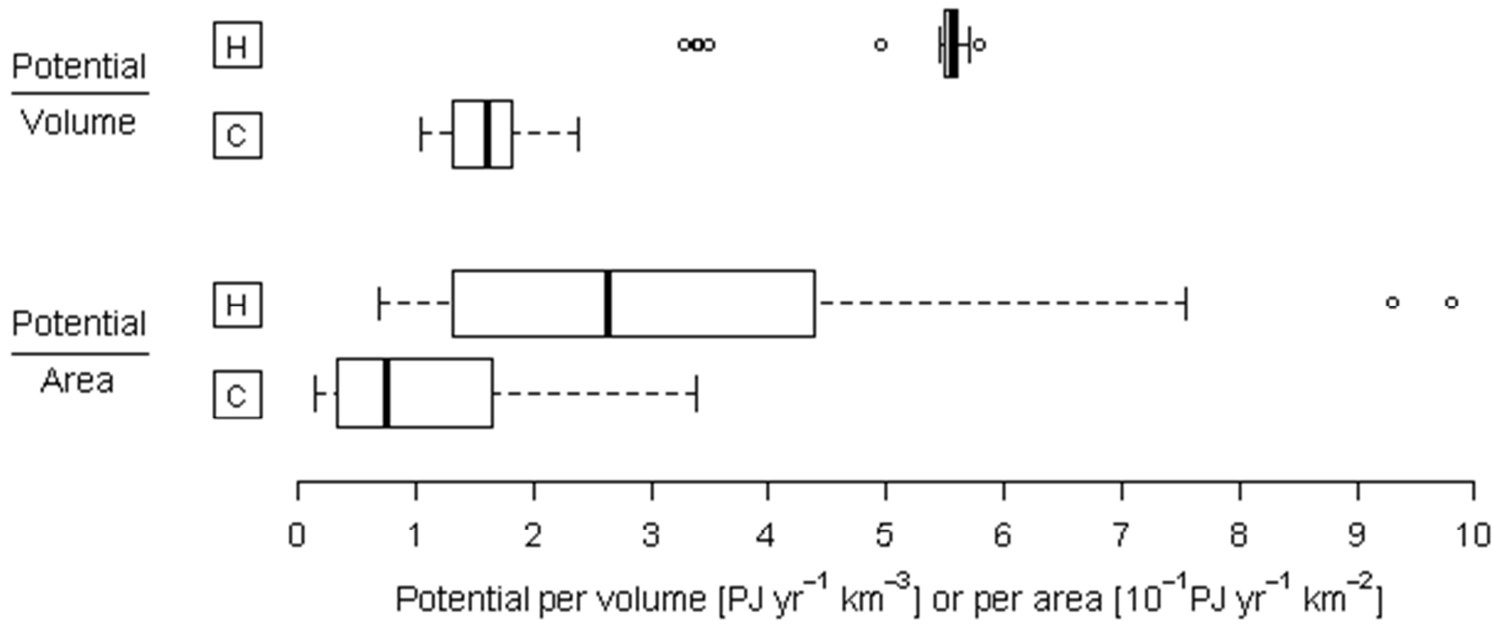

Figure 4 - Boxplots of the potentials per volume and per area for the considered lakes.

\subsubsection{Rivers}

374 The potentials and demands for the 35 considered rivers at 57 locations (see Appendices A and B) are 375 displayed in Figure 5. Related to the river flowrate, the range of the potentials for heat extraction are 0.014-0.27 $\mathrm{PJ} \mathrm{yr}^{-1} /\left(\mathrm{m}^{3} \mathrm{~s}^{-1}\right)$, and for heat disposal 0.011-0.20 PJ yr $\mathrm{r}^{-1} /\left(\mathrm{m}^{3} \mathrm{~s}^{-1}\right)$ (Figure 6). The geographical distributions of these potentials and demands are shown in Figure 7 (heat extraction) and Figure 8 (heat disposal).
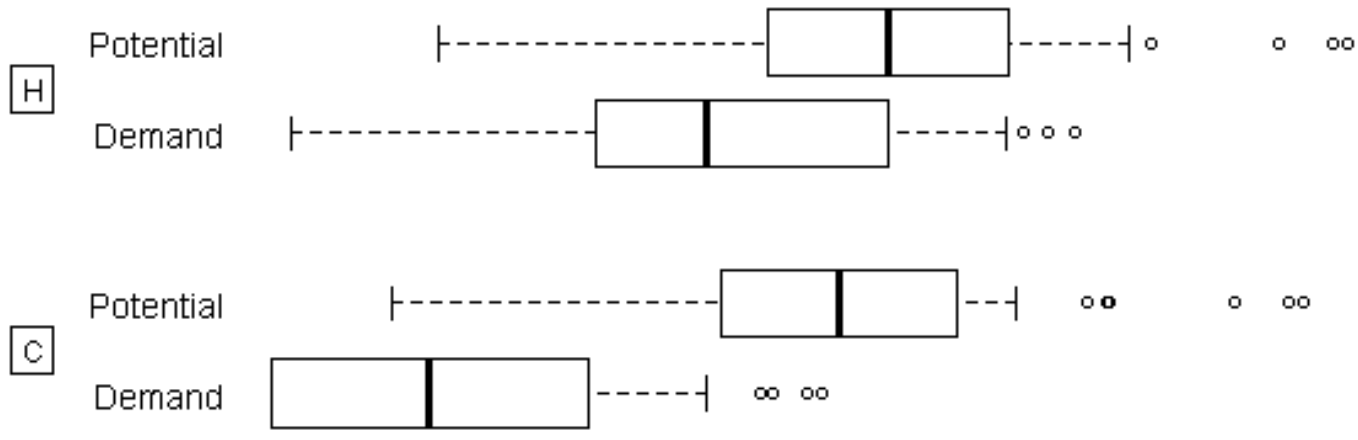

Thermal energy $\left[P J \mathrm{~J} \mathrm{r}^{-1}\right]$ $\mathrm{H}$ : heat extraction, $\mathrm{C}$ : heat disposal. The boxes show the $1^{\text {st }}, 2^{\text {nd }}$ and $3^{\text {rd }}$ quartiles. 


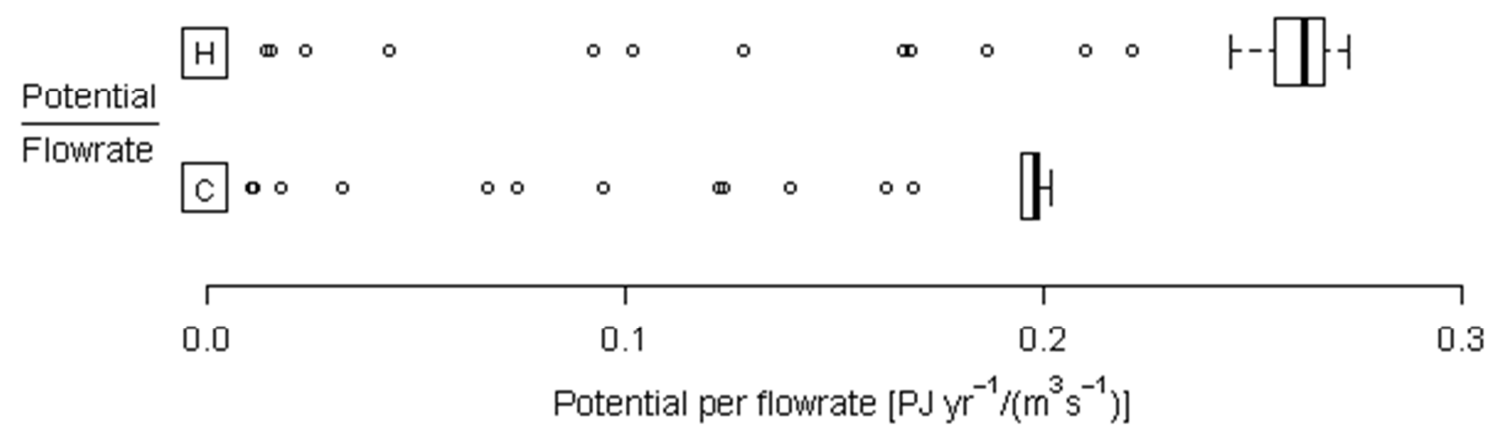
$\mathrm{H}$ : heat extraction, $\mathrm{C}$ : heat disposal. The boxes show the $1^{\text {st }}, 2^{\text {nd }}$ and $3^{\text {rd }}$ quartiles.

\section{Thermal energy (heat)}

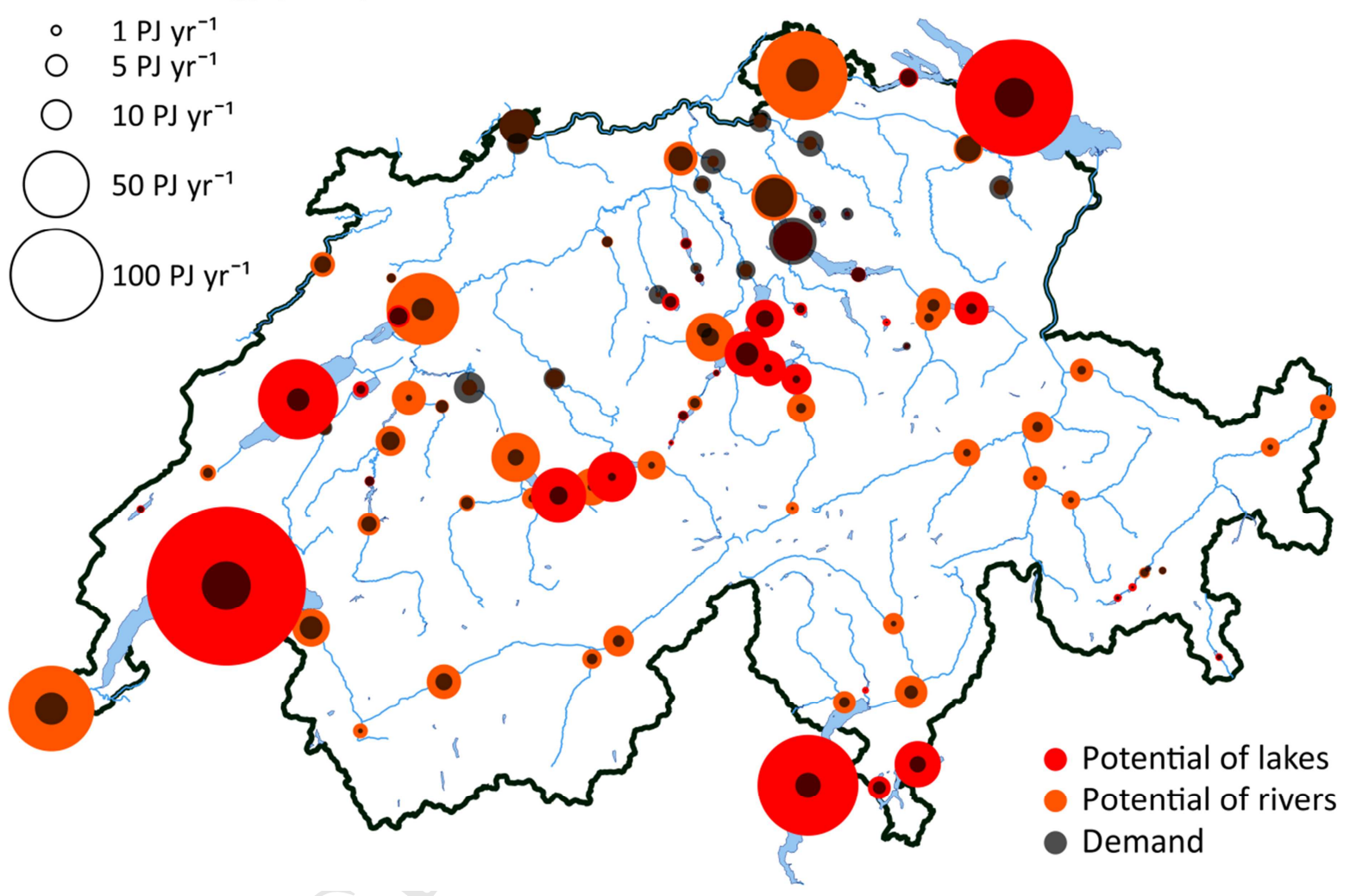

Figure 7 - Potentials of lakes and rivers in Switzerland for heat extraction, and regional demand. 


\section{Thermal energy (cold)}

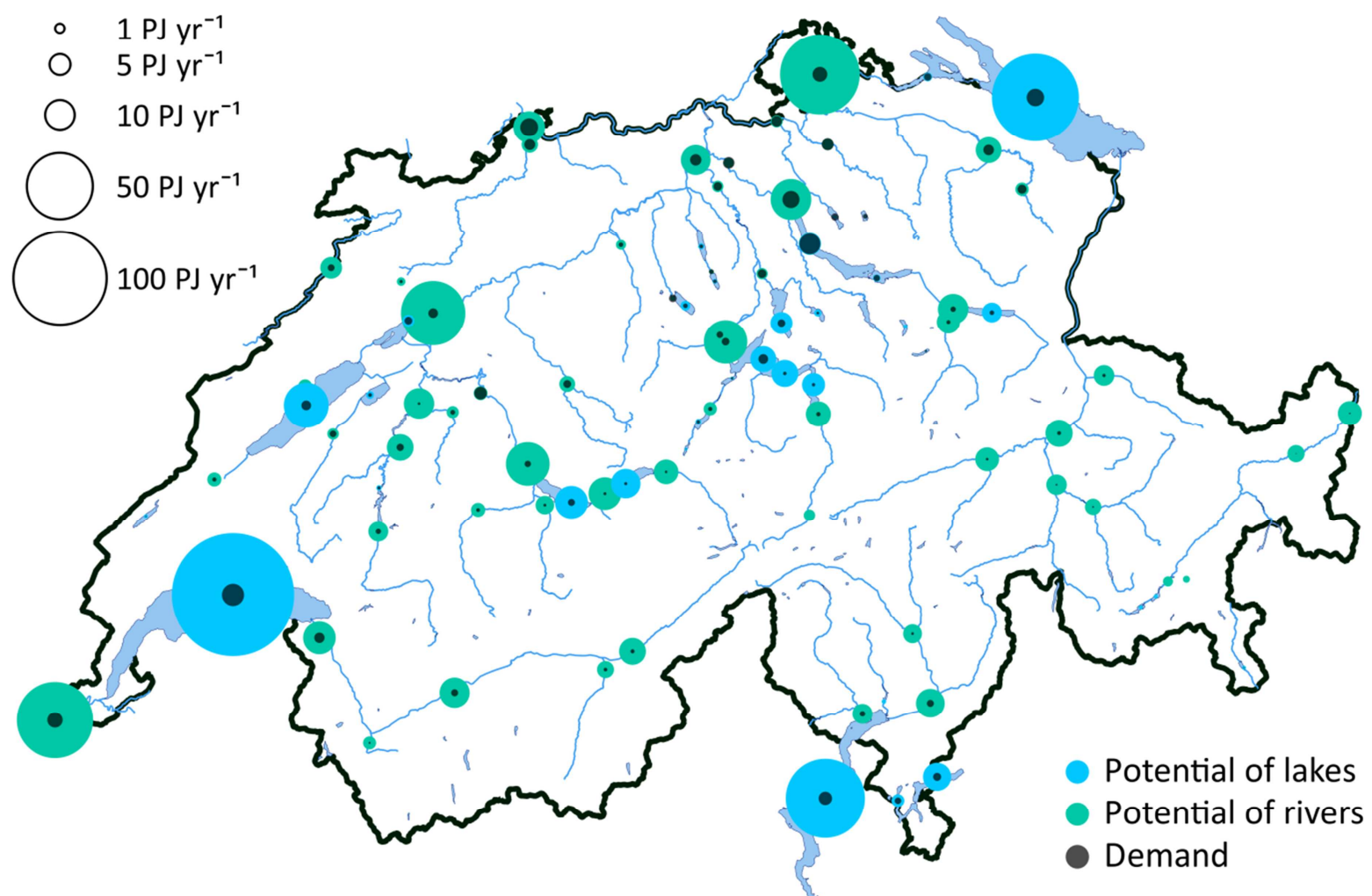

Figure 8 - Potentials of lakes and rivers in Switzerland for heat disposal, and regional demand.

\subsubsection{Lake outlets}

390 The potentials of the 9 considered lake outlets (see Appendices A and B) range from 0.4 to $43 \mathrm{PJ} \mathrm{yr}^{-1}$ 391 (Figure 9). As our method limits thermal use of lake outlets via a maximal thermocline drawdown, the outlets of larger lakes have larger potentials, and the flowrate is of secondary importance. 
Potential

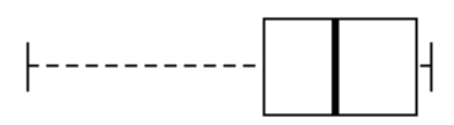

$\mathrm{C}$
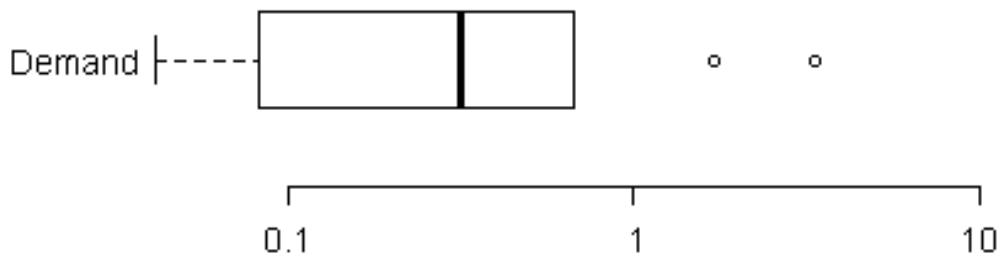

Thermal energy [PJ $\mathrm{yr}^{-1}$ ]

Figure 9- Boxplots of the estimated potentials and demands for the considered lake outlets (for heat disposal). The boxes show the $1^{\text {st }}, 2^{\text {nd }}$ and $3^{\text {rd }}$ quartiles.

\subsection{Modeling thermal use}

\subsubsection{Baseline results}

Table 4 shows the main results of our model for the two simulated lakes. These results relate to both the operation of thermal use (heat extraction and disposal) and the temperature impacts of the associated thermal discharge.

Table 4 - Summary of the results of the modeling of thermal use. The baseline parameter set is: $z_{\text {in }}=20 \mathrm{~m}$, $z_{\text {out }}=20 \mathrm{~m}, T_{\min }=2{ }^{\circ} \mathrm{C}, T_{\max }=15^{\circ} \mathrm{C}$.

\section{Upper Lake Constance Lower Lake Zurich} (1984 to 2015)

\begin{tabular}{|c|c|c|c|}
\hline & \multirow{2}{*}{$332 \mathrm{yr}^{-1}$} & \multirow{2}{*}{$330 \mathrm{yr}^{-1}$} \\
\hline \multirow{6}{*}{ 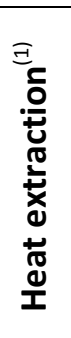 } & Number of heating days & & \\
\hline & Useful heating energy & 9.2 $\mathrm{PJ} \mathrm{yr}^{-1}$ & 13.6 $\mathrm{PJ} \mathrm{yr}^{-1}$ \\
\hline & External energy need for the heat pumps & $3.0 \mathrm{PJ} \mathrm{yr}^{-1}$ & $4.5 \mathrm{PJ} \mathrm{yr}^{-1}$ \\
\hline & Required volume of lake water & $0.41 \mathrm{~km}^{3} \mathrm{yr}^{-1}$ & $0.61 \mathrm{~km}^{3} \mathrm{yr}^{-1}$ \\
\hline & Operating flowrate & $14.3 \mathrm{~m}^{3} \mathrm{~s}^{-1}$ & $21.4 \mathrm{~m}^{3} \mathrm{~s}^{-1}$ \\
\hline & $\begin{array}{l}\text { Temperature difference between } \\
\text { discharge and intake }{ }^{(3)}\end{array}$ & $-3.58^{\circ} \mathrm{C}$ & $-3.56^{\circ} \mathrm{C}$ \\
\hline \multirow{5}{*}{ 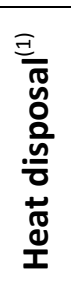 } & Number of cooling days & $63 \mathrm{yr}^{-1}$ & $69 \mathrm{yr}^{-1}$ \\
\hline & Useful cooling energy & 1.8 $\mathrm{PJ} \mathrm{yr}^{-1}$ & $2.5 \mathrm{PJ} \mathrm{yr}^{-1}$ \\
\hline & Required volume of lake water & $0.065 \mathrm{~km}^{3} \mathrm{yr}^{-1}$ & $0.077 \mathrm{~km}^{3} \mathrm{yr}^{-1}$ \\
\hline & Operating flowrate & $12.0 \mathrm{~m}^{3} \mathrm{~s}^{-1}$ & $13.0 \mathrm{~m}^{3} \mathrm{~s}^{-1}$ \\
\hline & $\begin{array}{l}\text { Temperature difference between } \\
\text { discharge and intake }{ }^{(3)}\end{array}$ & $+6.699^{\circ} \mathrm{C}$ & $+7.77^{\circ} \mathrm{C}$ \\
\hline \multirow{7}{*}{ 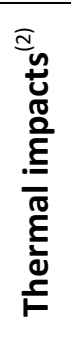 } & Mean winter profile & -0.03 to $-0.02{ }^{\circ} \mathrm{C}$ & -0.33 to $-0.16^{\circ} \mathrm{C}$ \\
\hline & Mean spring profile & -0.04 to $-0.02{ }^{\circ} \mathrm{C}$ & -0.35 to $-0.18^{\circ} \mathrm{C}$ \\
\hline & Mean summer profile & -0.03 to $0.00^{\circ} \mathrm{C}$ & -0.35 to $+0.02^{\circ} \mathrm{C}$ \\
\hline & Mean fall profile & -0.03 to $0.00^{\circ} \mathrm{C}$ & -0.43 to $+0.11^{\circ} \mathrm{C}$ \\
\hline & Surface water $(10 \mathrm{~m} \text { depth })^{(4)}$ & -0.04 to $+0.02{ }^{\circ} \mathrm{C}$ & -0.38 to $+0.24^{\circ} \mathrm{C}$ \\
\hline & Mid-depth water (40/50 m depth) $)^{(4)}$ & -0.03 to $-0.02{ }^{\circ} \mathrm{C}$ & -0.40 to $-0.22{ }^{\circ} \mathrm{C}$ \\
\hline & Deepwater $(100 / 150 \mathrm{~m} \text { depth) })^{(4)}$ & -0.03 to $-0.02{ }^{\circ} \mathrm{C}$ & -0.19 to $-0.16^{\circ} \mathrm{C}$ \\
\hline
\end{tabular}

\footnotetext{
(1) All values are averages over the indicated simulation period.

(2) Ranges of temperature alteration are given (minimum and maximum values).

(3) Weighed with the corresponding flowrate.

${ }^{(4)}$ Values are averages for each day of year over the indicated simulation period.
} 
408 Our modeling work exposes how the four variable parameters affect the thermal use of Upper Lake 409 Constance (full results in Appendix D):

- $\boldsymbol{z}_{\text {in }}$ (intake depth). Expectedly, a shallower intake is advantageous for heat extraction, while a deeper intake is advantageous for heat disposal (Figure 10(a) and (b)). For heating, optimal efficiency is achieved with an intake at $20 \mathrm{~m}$ depth or above, but greater depths are only slightly less favorable. The power-averaged COP decreases from $3.10\left(z_{\text {in }}=10 \mathrm{~m}\right)$ to 2.96 $\left(z_{\text {in }}=100 \mathrm{~m}\right)$. For cooling, best conditions are found below $40 \mathrm{~m}$ depth, while shallower depths are very unfavorable. In lakes that stratify inversely in winter (common at higher elevations or under cold winter conditions), a shallow intake is also unfavorable for heat extraction.

- $\boldsymbol{z}_{\text {out }}$ (discharge depth). Operation of thermal use is independent of $z_{\text {out }}$.

- $\boldsymbol{T}_{\text {min }}$ (minimal temperature for thermal discharge after heat extraction). A lower $T_{\min }$ increases the efficiency of the process. In other words, one can operate with a higher $\Delta T_{\text {heat }}$ and therefore lower water flows (Figure 11(a)). Typically, $T_{\min }$ will be determined by the source temperature and by the characteristics of the heat pumps. The model shows that if $T_{\min }>2{ }^{\circ} \mathrm{C}$, much larger water volumes are required to extract a given amount of heat. If $T_{\min } \geq 4{ }^{\circ} \mathrm{C}$, the frequency of periods where heat extraction is impossible (as the intake water would then be colder than the discharged water) increases greatly.

- $\boldsymbol{T}_{\max }$ (maximal temperature for thermal discharge after heat disposal). A larger $T_{\max }$ increases the efficiency of the process. In other words, one can operate with a higher $\Delta T_{\text {cool }}$ and therefore lower water flows (Figure 11(b)). The model results show that if $T_{\max }<15^{\circ} \mathrm{C}$, much larger water volumes are required to dispose of a given amount of heat. 

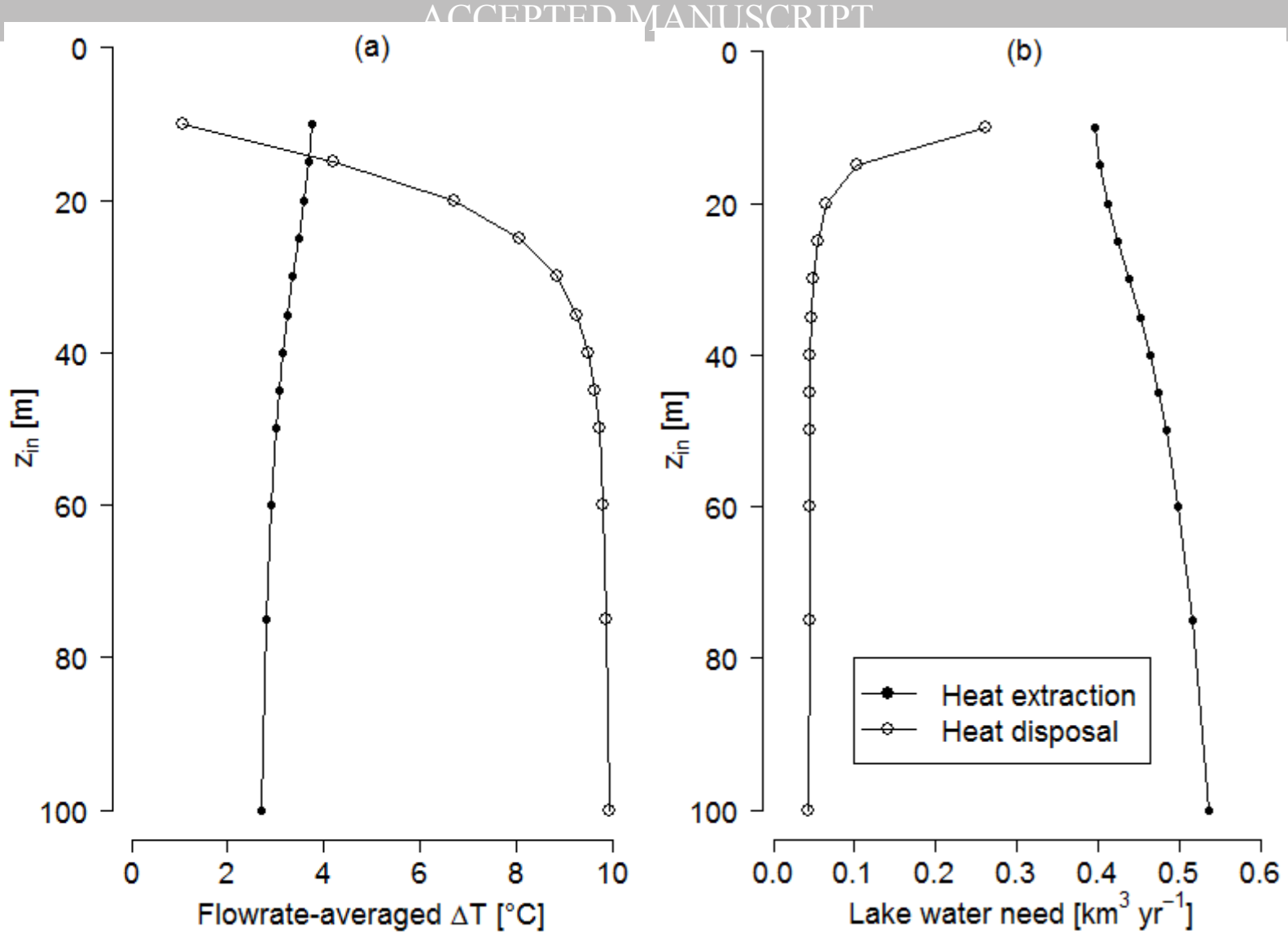

Figure 10 - Upper Lake Constance: effect of the intake depth on (a) the absolute temperature difference between discharge and intake and (b) the yearly volume of lake water needed. In (a), the temperature difference is weighed with the flowrate and averaged over the simulation period.
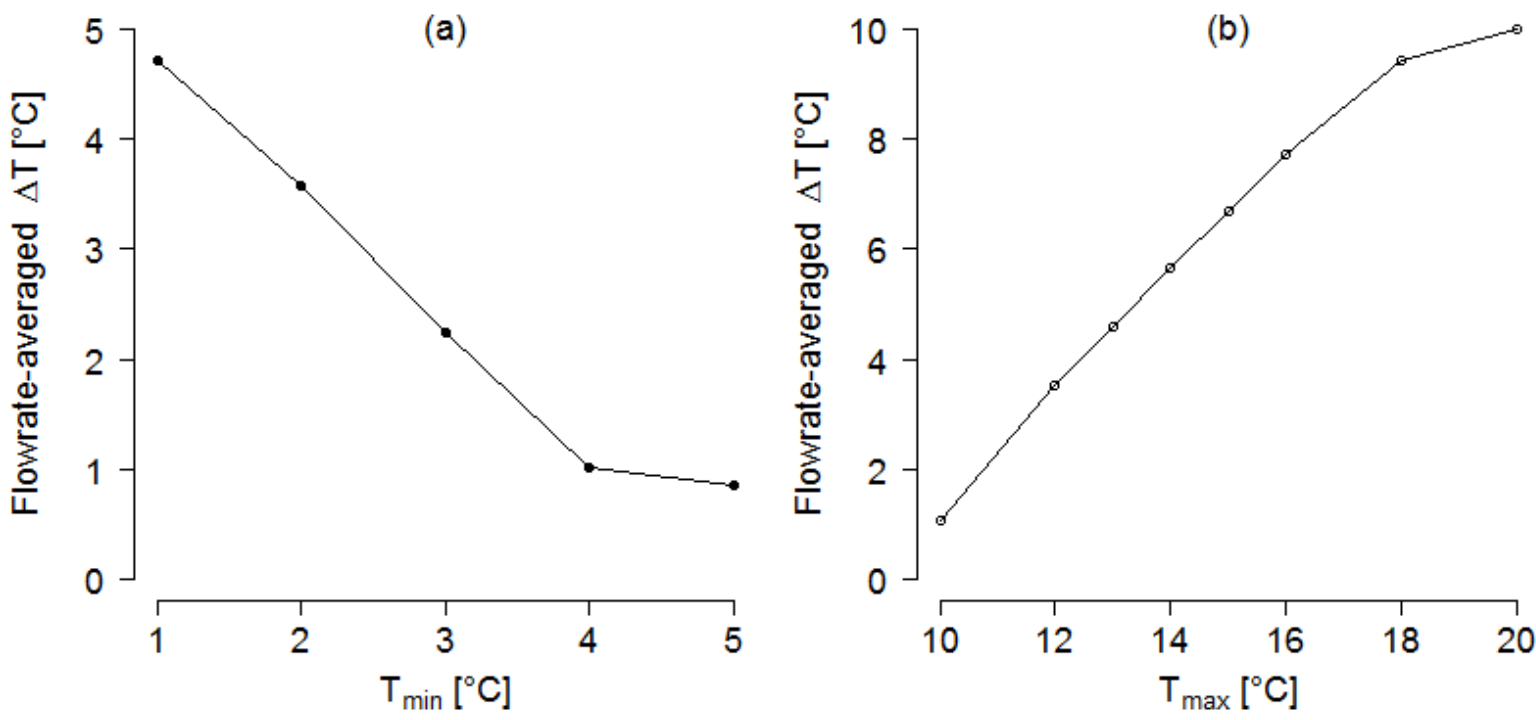

Figure 11 - Upper Lake Constance: absolute temperature difference between discharge and intake as a function of (a) the minimal discharge temperature (heat extraction) and (b) the maximal discharge temperature (heat disposal). The temperature difference is weighed with the flowrate and averaged over the simulation period. 
440 Overall, realistic thermal use results in a slight cooling of a lake (Table 4). This cooling is stronger in winter and spring than in summer and fall. This illustrates the lag between thermal use and thermal impacts in the lake, which progressively accumulate over the heating or cooling season. Throughout the water column, thermal use causes an overall cooling of the hypolimnion and of the water at intermediate depths, while in the epilimnion the impacts vary seasonally: cooling in winter and spring, and no effect or slight warming in summer and fall (Figure 12).

In Upper Lake Constance, the model showed that thermal use has little impacts on the lake. The absolute daily-averaged temperature difference does not exceed $0.05{ }^{\circ} \mathrm{C}$, and the average seasonal profiles deviate by up to $0.04{ }^{\circ} \mathrm{C}$. In Lower Lake Zurich, thermal use is comparatively more intense and, in the extreme cases, causes the daily-averaged temperatures to be up to $0.63^{\circ} \mathrm{C}$ cooler or $0.32{ }^{\circ} \mathrm{C}$ warmer. As the thermal impacts are significantly stronger in Lower Lake Zurich, this case was used to investigate the effect of the four variable parameters (full results in Appendix D):

- $\boldsymbol{z}_{\mathbf{i n}}$. Thermal impacts tend to increase with the depth of the intake. This is primarily an effect of water translocation, as considerable volumes are moved from the intake to the discharge depth $z_{\text {out }}=20 \mathrm{~m}$. In particular, a deeper intake results in colder lake temperatures in fall but potentially in a stronger warming of the mid-depth layers (at $\sim 40 \mathrm{~m}$ depth).

- $\boldsymbol{z}_{\text {out }}$. As expected, thermal impacts are generally stronger in the depth range of the discharge, for both cooling and warming. Shallow discharge (common in practice) reduces lake cooling but may increase summer temperatures in the surface layers.

- $\boldsymbol{T}_{\mathbf{m i n}}$. Variations of the minimum discharge temperature strongly affect the thermal impacts in the lake. Thermal impacts are the lowest when $T_{\min } \leq 2^{\circ} \mathrm{C}$. This effect is partly due to the fact that the required volume of lake water is much higher if $T_{\min }$ increases (Section 5.3.2).

- $\boldsymbol{T}_{\text {max }}$. Modeled thermal impacts are not significantly affected by the maximum discharge temperature. A higher $T_{\max }$ tends to result in a stronger warming in the surface layers, which can be understood as the result of a warmer plume accumulating there. 


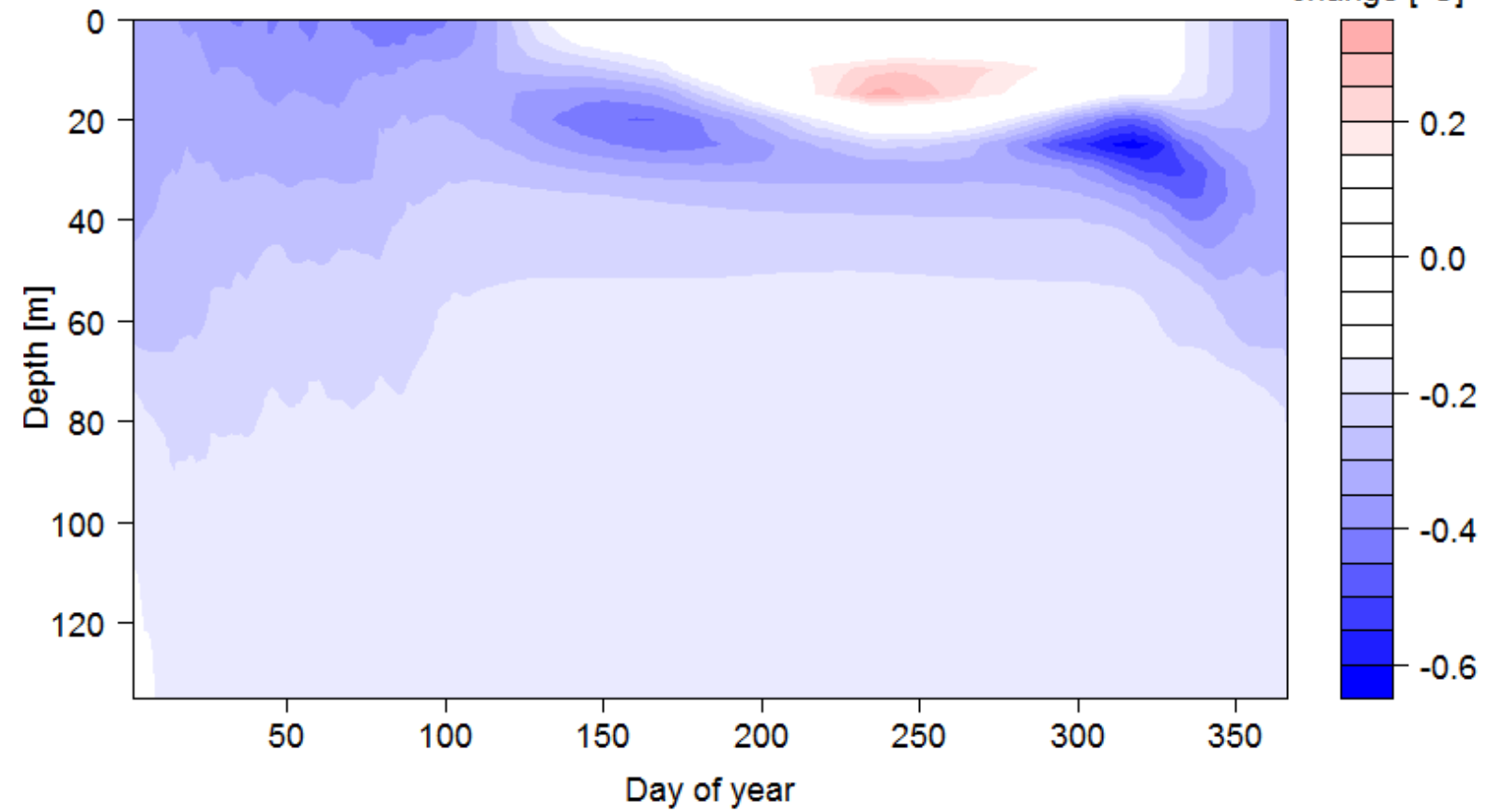

Figure 12 - Lower Lake Zurich: contour plot of the daily-averaged temperature changes due to the thermal use defined in Figure 2 and Table 1, using the baseline parameter set.

\section{Discussion}

For most lakes and rivers in Switzerland, the estimated potentials for heat extraction and disposal are an order of magnitude above the maximum regional demands for heating and cooling. This highlights the large thermal potential offered by lakes and rivers in Switzerland. However, it does not entirely rule out the fact that measurable impacts may occur through thermal use of the considered waterbodies. The estimates also identify specific cases where the regional demand is near or higher than the available potential and for which thermal uses must be particularly well managed. In Switzerland, heat extraction from waterbodies can reduce the use of fossil fuels, and heat disposal to waterbodies can replace energy-intensive chillers.

The outcomes of our analysis are not necessarily directly transferable to other world regions, where other local energy sources, for example geothermal energy [56], may be available. Our work shows that very densely populated areas have a demand for heating and cooling that can exceed the potential of local waterbodies (an example in Switzerland is the region of Zurich). For rivers flowing by several large users, the impact of the accumulated thermal discharge on the downstream users cannot be neglected. In particular, cooling of power plants is critical, as it induces only warming of the river (generally more problematic than cooling) and as there are usually very large amounts of heat at stake.

\subsection{Refinement of the estimates}

Our potential estimates provide an order of magnitude but cannot be considered as accurate for a specific lake or river. Finer estimates would require better knowledge of the processes acting in each 
waterbody. Consideration of seasonality would also improve the prediction of the available potential and possible impacts of thermal use throughout the year [28].

In lakes, a reliable assessment of the conditions under which specific temperature alterations are critical for lake ecology (e.g., disruption of vertical mixing or significant loss of habitat for a species) is necessary to better estimate the acceptable potential. This involves a good understanding of the dispersal of the thermal plume(s), both within and outside the lake. An appropriate tool for such assessment can be modeling, given the many interacting processes such as atmospheric forcing, water currents, topography, outlet design, and operating conditions [44].

In rivers, consideration of ecological aspects allows for better potential estimates. In particular, the fish community and their periods of development, spawning and migration are of great importance. It would then be possible to define a maximal thermal use (e.g., as a maximal temperature difference) that is ecologically adequate as a function of season, river type and ecological properties [57].

\subsection{Considerations for planning and operation}

Careful planning of thermal use infrastructure is decisive for the economic and technical viability of the system. Many factors affect the effectiveness of thermal use infrastructure and the impacts of thermal discharge on the aquatic environment. Four of these factors are discussed below, and a summary of typical cases requiring particular design or management measures is given in Appendix $\mathrm{F}$.

The location of the water intake is a critical parameter: depending on the thermal use (heating, cooling, or both), one may prefer high, low and/or stable temperatures during specific seasons. In rivers, which are rather well-mixed, knowledge of the seasonal flow and temperature regimes is necessary. In lakes, energetically optimal location and depth can be determined using a long series of monitored or modelled temperature profiles [58].

\section{Rivers: flow and temperature regime}

Most rivers experience periods with flowrates significantly lower than the average flowrate. During these periods, the potential for thermal use is reduced. In Switzerland, the period with the lowest flow is usually around February for rivers with a glacial or nival flow regime, or in fall for rivers with a pluvial flow regime [59]. In addition, during hot summer periods, rivers can reach temperature maxima that reduce their potential for heat disposal [60,61]. Lowland rivers downstream of large lakes are particularly vulnerable to this problem, which is also exacerbated during periods of low flow. As a result, heat extraction may be periodically problematic in such rivers. They are, however, generally appropriate for heat extraction in winter, as their temperature very rarely drops below $4{ }^{\circ} \mathrm{C}$. On the contrary, rivers that are directly fed by a mountainous drainage basin are often too cold for efficient heat extraction in winter but are well-suited for heat disposal in summer.

The temperature limits used in our work $\left( \pm 1.5^{\circ} \mathrm{C}\right.$, in accordance with the Swiss legislation) may not always be sufficient to avoid negative impacts. First, warming is often more critical than cooling. Secondly, the thermal tolerance of an ecosystem depends much on its organisms and varies seasonally [42]. We advise that temperature limits should take these factors into account, for example by progressively restricting heat disposal when river temperature increases (while possibly allowing for more heat extraction), and by limiting temperature alterations during sensitive periods (e.g., fish spawning). 
Shallow layers of lakes offer ideal conditions for organisms (more light, warmer temperature, etc.) and are therefore more prone to biological activity. Using this water can result in operating difficulties, such as suction of organisms, biofilm formation and colonization by mussels. These problems, known as biofouling (Appendix G), concern the primary loop: pipes, filters and heat exchangers directly exposed to lake or river water [62]. Biofouling usually causes a reduction in efficiency of heat exchange and an increase in operating costs (due to cleaning requirements). In particular, the upper $15 \mathrm{~m}$ of lakes in Switzerland should be avoided, as algae, zooplankton and fish often thrive there (especially during the warmer seasons). Zebra mussels are rarely found below $15 \mathrm{~m} \mathrm{[63];} \mathrm{their} \mathrm{presence} \mathrm{also} \mathrm{depends} \mathrm{much} \mathrm{on} \mathrm{calcite} \mathrm{concentration,} \mathrm{pH}$ and nutrient availability [64]. However, economic arguments must also be considered, given that long and deep underwater pipes are more expensive to build and maintain.

Lakes usually contain more nutrients in the deeper layers. As a result, translocation of deepwater to the surface layers of a lake or directly to the outflow may induce nutrient fluxes [43]. This is expected to be particularly problematic in eutrophic lakes.

\section{Design of the thermal discharge}

Depending on the situation, one may prefer a thermal discharge to mix as rapidly as possible within the receiving waterbody, or instead to form a thermal plume that only affects a small part of the waterbody.

The first case is typically favored if the thermal pollution is very small in relation to the heat capacity of the waterbody. Local impacts are then avoided thanks to rapid mixing and global impacts are assumedly negligible. This case can be implemented through specific design choices for the outlet: faster discharge velocity to enhance mixing, distribution of the discharge at several locations, premixing with ambient water to reduce the temperature difference, etc.

The second case may be desired in the situation of a strong thermal discharge, the impacts of which should remain in a controlled area and not spread to the entire waterbody or other waterbodies. In lakes, this is for example achieved via the discharge of warm water near the surface. This water islighter and remains near the surface and can rapidly exchange heat with the atmosphere, effectively dissipating the added heat [65], which does not get stored in the lake. In rivers, a warm thermal discharge could be dispersed as a surface flow in order to intensify heat exchange with the atmosphere. A thermal discharge can also be designed to enter a river on the side, whereby it can flow along the river for a long distance (depending on the flow turbulence) [66]. The main flow of the river is then considerably less affected over some distance and could still provide shelter for sensitive species or a migratory corridor for fish.

Impacts of warm thermal discharge can be attenuated if part of the heat is lost before the discharge enters the waterbody. This is typically achieved by leaving the warm water in contact with the atmosphere - for example in cooling ponds or channels [67] - before it is discharged. Another technique is to discharge the warm water as a spray, which will enhance evaporation and heat exchange with the air, thereby cooling the discharge. 
Generally, demand for heating and cooling follows a strong seasonal pattern (Figure 2). There are, however, applications requiring heat all year (e.g., domestic warm water, swimming pools or industrial processes) or cold all year (e.g., food services, computer systems or industrial processes). If, within a given thermal use, heat can be exchanged between nearby users with different needs, thermal emissions to the environment can be reduced substantially. It is therefore essential to consider other potential users during the planning phase.

\subsection{Interactions with climate change}

Climate change will have an ever-growing impact on the environment over the $21^{\text {st }}$ century, by the end of which substantial alterations will have taken place. These encompass global warming, changes in precipitation patterns, change in biological communities, etc., with consequences for all ecosystems [68]. Waterbodies will also be affected. Climate change induces a warming of lakes, which will expectedly be stronger for surface layers. Climate change also results in warmer rivers and affects their hydrological regime, expectedly shifting the flow regime earlier in the year.

Regarding thermal use of lakes and rivers, several effects are acting. First, climate change pushes the demand towards less heating and more cooling [53,54] (among other drivers - Table 3). Secondly, waterbodies are becoming warmer, which makes them more suitable for heat extraction, but less suitable for heat disposal [69]. Changes in river flow will also affect the potential for thermal use of rivers.

We are grateful to the Federal Office for the Environment (FOEN) for funding this work. We also thank the different institutes which provided the data used here: the cantonal authorities for data on lake temperatures and Secchi depths; FOEN for River flowrates and temperatures; the Federal Office of Meteorology and Climatology (MeteoSwiss) for meteorological data, including heating and cooling degree-days; the Federal Office of Topography (swisstopo) for geographical data (lakes, rivers and communes) used in the GIS approach; the Federal Statistical Office (FSO) for population data.

\section{References}

[1] L. Rybach, Shallow Systems: Geothermal Heat Pumps, in: A. Sayigh (Ed.), Compr. Renew. Energy, Elsevier, Oxford, 2012: pp. 189-207. doi:10.1016/B978-0-08-087872-0.00704-6.

[2] G.W. Huttrer, Geothermal heat pumps: An increasingly successful technology, Renew. Energy. 10 (1997) 481-488. doi:10.1016/0960-1481(96)00107-3.

[3] I. Sarbu, C. Sebarchievici, General review of ground-source heat pump systems for heating and cooling of buildings, Energy Build. 70 (2014) 441-454. doi:10.1016/j.enbuild.2013.11.068.

[4] L. Ni, J. Dong, Y. Yao, C. Shen, D. Qv, X. Zhang, A review of heat pump systems for heating and cooling of buildings in China in the last decade, Renew. Energy. 84 (2015) 30-45. doi:10.1016/j.renene.2015.06.043.

[5] H. Averfalk, P. Ingvarsson, U. Persson, M. Gong, S. Werner, Large heat pumps in Swedish district heating systems, Renew. Sustain. Energy Rev. 79 (2017) 1275-1284. doi:10.1016/j.rser.2017.05.135. 
[6] L. Wen, Evaluation the performance of lake water used as heat source for heat pump system in a typical Japanese resident building, Int. J. Geomate. 12 (2017) 127-133.

[7] M.S. Mitchell, J.D. Spitler, Open-loop direct surface water cooling and surface water heat pump systems-A review, HVACR Res. 19 (2013) 125-140. doi:10.1080/10789669.2012.747374.

[8] J.D. Spitler, M.S. Mitchell, 8 - Surface water heat pump systems, in: S.J. Rees (Ed.), Adv. GroundSource Heat Pump Syst., Woodhead Publishing, 2016: pp. 225-246. doi:10.1016/B978-0-08100311-4.00008-X.

[9] B. Rezaie, M.A. Rosen, District heating and cooling: Review of technology and potential enhancements, Appl. Energy. 93 (2012) 2-10. doi:10.1016/j.apenergy.2011.04.020.

[10] M. Pellegrini, A. Bianchini, The Innovative Concept of Cold District Heating Networks: A Literature Review, Energies. 11 (2018) 236. doi:10.3390/en11010236.

[11] W. Zheng, T. Ye, S. You, H. Zhang, The thermal performance of seawater-source heat pump systems in areas of severe cold during winter, Energy Convers. Manag. 90 (2015) 166-174. doi:10.1016/j.enconman.2014.10.050.

[12] EHPA, The World's Largest "Natural" District Heat Pump, Eur. Heat Pump Assoc. (2015). http://www.ehpa.org/about/news/article/the-worlds-largest-natural-district-heat-pump/ (accessed August 15, 2018).

[13] J. Epting, M.H. Müller, D. Genske, P. Huggenberger, Relating groundwater heat-potential to city-scale heat-demand: A theoretical consideration for urban groundwater resource management, Appl. Energy. 228 (2018) 1499-1505. doi:10.1016/j.apenergy.2018.06.154.

[14] F. Stauffer, P. Bayer, P. Blum, N.M. Giraldo, W. Kinzelbach, Thermal use of shallow groundwater, CRC Press, 2013. doi:10.1201/b16239.

[15] S. Jardón, A. Ordóñez, R. Álvarez, P. Cienfuegos, J. Loredo, Mine Water for Energy and Water Supply in the Central Coal Basin of Asturias (Spain), Mine Water Environ. 32 (2013) 139-151. doi:10.1007/s10230-013-0224-x.

[16] D. Banks, H. Skarphagen, R. Wiltshire, C. Jessop, Mine water as a resource: space heating and cooling via use of heat pumps, Land Contam. Reclam. 11 (2003) 191-198. doi:10.2462/09670513.814.

[17] S. Kindaichi, D. Nishina, L. Wen, T. Kannaka, Potential for using water reservoirs as heat sources in heat pump systems, Appl. Therm. Eng. 76 (2015) 47-53. doi:10.1016/j.applthermaleng.2014.10.091.

[18] E. Hiltunen, B. Martinkauppi, L. Zhu, A. Mäkiranta, M. Lieskoski, J. Rinta-Luoma, Renewable, carbon-free heat production from urban and rural water areas, J. Clean. Prod. 153 (2017) 397404. doi:10.1016/j.jclepro.2015.10.039.

[19] J. Frijns, J. Hofman, M. Nederlof, The potential of (waste)water as energy carrier, Energy Convers. Manag. 65 (2013) 357-363. doi:10.1016/j.enconman.2012.08.023.

[20] O. Wanner, Wärmerückgewinnung aus Abwassersystemen: Schlussbericht, Eawag, 2004. http://www.eawag.ch/fileadmin/Domain1/Abteilungen/eng/projekte/abwasser/Waermerueck gewinnung/BFE_Schlussbericht.pdf (accessed December 19, 2016).

[21] L.T. Wong, K.W. Mui, Y. Guan, Shower water heat recovery in high-rise residential buildings of Hong Kong, Appl. Energy. 87 (2010) 703-709. doi:10.1016/j.apenergy.2009.08.008.

[22] G. Fink, M. Schmid, A. Wüest, Large lakes as sources and sinks of anthropogenic heat: Capacities and limits, Water Resour. Res. 50 (2014) 7285-7301. doi:10.1002/2014WR015509.

[23] B.A. Sinokrot, H.G. Stefan, Stream temperature dynamics: Measurements and modeling, Water Resour. Res. 29 (1993) 2299-2312.

[24] M. Toffolon, S. Piccolroaz, B. Majone, A.-M. Soja, F. Peeters, M. Schmid, A. Wüest, Prediction of surface temperature in lakes with different morphology using air temperature, Limnol. Oceanogr. 59 (2014) 2185-2202. doi:10.4319/lo.2014.59.6.2185.

[25] D. Bouffard, U. Lemmin, Kelvin waves in Lake Geneva, J. Gt. Lakes Res. 39 (2013) 637-645. doi:10.1016/j.jglr.2013.09.005.

[26] C.E. Raptis, M.T.H. van Vliet, S. Pfister, Global thermal pollution of rivers from thermoelectric power plants, Environ. Res. Lett. 11 (2016) 104011. doi:10.1088/1748-9326/11/10/104011.

[27] T.E.L. Langford, Ecological effects of thermal discharges, Springer Netherlands, London, 1990. 
[28] F. Verones, M.M. Hanafiah, S. Pfister, M.A.J. Huijbregts, G.J. Pelletier, A. Koehler, Characterization factors for thermal pollution in freshwater aquatic environments, Environ. Sci. Technol. 44 (2010) 9364-9369. doi:10.1021/es102260c.

[29] O. Büyükalaca, F. Ekinci, T. Yılmaz, Experimental investigation of Seyhan River and dam lake as heat source-sink for a heat pump, Energy. 28 (2003) 157-169. doi:10.1016/S03605442(02)00088-9.

[30] X. Chen, G. Zhang, J. Peng, X. Lin, T. Liu, The performance of an open-loop lake water heat pump system in south China, Appl. Therm. Eng. 26 (2006) 2255-2261. doi:10.1016/j.applthermaleng.2006.03.009.

[31] R.J. Stewart, W.M. Wollheim, A. Miara, C.J. Vörösmarty, B. Fekete, R.B. Lammers, B. Rosenzweig, Horizontal cooling towers: Riverine ecosystem services and the fate of thermoelectric heat in the contemporary Northeast US, Environ. Res. Lett. 8 (2013) 025010. doi:10.1088/1748-9326/8/2/025010.

[32] IEA, Technology roadmap - Energy-efficient buildings: Heating and cooling equipment, International Energy Agency (IEA), 2011.

[33] M. Zogg, Wärmepumpen, "Geothermie - die Energie des 21. Jahrhunderts" Zertifikatslehrgang ETH, 2009. http://zogg-engineering.ch/Publi/WP_ETH_Zogg.pdf.

[34] P. Kunz, T. Afjei, W. Betschart, P. Hubacher, R. Löhrer, A. Müller, V. Prochaska, Pompes à chaleur: Planification, Optimisation, Fonctionnement, Entretien, Bundesamt für Energie (BFE), Bern, 2008. http://www.bfe.admin.ch/php/modules/publikationen/stream.php?extlang=fr\&name=fr_3693 29917.pdf.

[35] A. Hepbasli, Y. Kalinci, A review of heat pump water heating systems, Renew. Sustain. Energy Rev. 13 (2009) 1211-1229. doi:10.1016/j.rser.2008.08.002.

[36] H. Kammer, Thermische Seewassernutzung in Deutschland, Springer Fachmedien Wiesbaden, Wiesbaden, 2018. doi:10.1007/978-3-658-20901-8.

[37] S. Zou, X. Xie, Simplified model for coefficient of performance calculation of surface water source heat pump, Appl. Therm. Eng. 112 (2017) 201-207. doi:10.1016/j.applthermaleng.2016.10.081.

[38] H. Pieper, T.S. Ommen, W.B. Markussen, B. Elmegaard, Optimal usage of low temperature heat sources to supply district heating by heat pumps, in: Proc. ECOS 2017, San Diego, United States, 2017.

[39] L. Schibuola, M. Scarpa, Experimental analysis of the performances of a surface water source heat pump, Energy Build. 113 (2016) 182-188. doi:10.1016/j.enbuild.2015.12.048.

[40] A. Gaudard, C. Weber, T.J. Alexander, S. Hunziker, M. Schmid, Impacts of using lakes and rivers for extraction and disposal of heat, Wiley Interdiscip. Rev. Water. 5 (2018) e1295. doi:10.1002/wat2.1295.

[41] R.H. Koschel, T. Gonsiorczyk, L. Krienitz, J. Padisák, W. Scheffler, Primary production of phytoplankton and nutrient metabolism during and after thermal pollution in a deep, oligotrophic lowland lake (Lake Stechlin, Germany), Proc.-Int. Assoc. Theor. Appl. Limnol. 28 (2002) 569-575.

[42] A. Gaudard, C. Weber, T.J. Alexander, S. Hunziker, M. Schmid, Impacts of using lakes and rivers for extraction and disposal of heat, WIREs Water. submitted (2017).

[43] N. Munz, Abwärmeimmissionen in Gewässer: Relevanzanalyse, BMG Engineering AG, 2009.

[44] L. Råman Vinnå, A. Wüest, D. Bouffard, Physical effects of thermal pollution in lakes, Water Resour. Res. 53 (2017) 3968-3987. doi:10.1002/2016WR019686.

[45] R. Lund, U. Persson, Mapping of potential heat sources for heat pumps for district heating in Denmark, Energy. 110 (2016) 129-138. doi:10.1016/j.energy.2015.12.127.

[46] swisstopo, swissBOUNDARIES3D, Vector200, DV 5704000 000, reproduced by permission of swisstopo / JA100119, (2017).

[47] T. Jankowski, D.M. Livingstone, H. Bührer, R. Forster, P. Niederhauser, Consequences of the 2003 European heat wave for lake temperature profiles, thermal stability, and hypolimnetic oxygen depletion: Implications for a warmer world, Limnol. Oceanogr. 51 (2006) 815-819. doi:10.4319/lo.2006.51.2.0815. 
[48] W.R. Herb, H.G. Stefan, Modified equilibrium temperature models for cold-water streams, Water Resour. Res. 47 (2011). http://onlinelibrary.wiley.com/doi/10.1029/2010WR009586/full.

[49] G.-H. Goudsmit, H. Burchard, F. Peeters, A. Wüest, Application of k- $\epsilon$ turbulence models to enclosed basins: The role of internal seiches, J. Geophys. Res. Oceans. 107 (2002) 3230. doi:10.1029/2001JC000954.

[50] Prognos AG, Infras AG, TEP Energy GmbH, Analyse des schweizerischen Energieverbrauchs 2000 - 2014 nach Verwendungszwecken, Bundesamt für Energie (BFE), 2015. http://www.bfe.admin.ch/php/modules/publikationen/stream.php?extlang=de\&name=de_993 701044.pdf\&endung=Analyse\%20des\%20schweizerischen\%20Energieverbrauchs\%202000\%20\%202014\%20nach\%20Verwendungszwecken.

[51] R. Dumortier, T. Lang, B. Schmutz, Elektrizitätsbedarf fürs Kühlen in der Schweiz, EnergieSchweiz, Zürich, 2012.

[52] BFS, Szenarien zur Bevölkerungsentwicklung der Schweiz 2015-2045, Bundesamt für Statistik (BFS), Neuchâtel, 2015.

[53] CH2014-Impacts, Toward Quantitative Scenarios of Climate Change Impacts in Switzerland, OcCR, FOEN, MeteoSwiss, C2SM, Agroscope and ProClim, Bern, Switzerland, 2014. http://ch2014-impacts.ch/res/files/CH2014-Impacts_report.pdf.

[54] OcCC, Klimaänderung und die Schweiz 2050: Erwartete Auswirkungen auf Umwelt, Gesellschaft und Wirtschaft, Organe consultatif sur les changements climatiques, Bern, 2007. www.occc.ch/products/ch2050/PDF_D/CH2050.pdf.

[55] Prognos AG, Ex-Post-Analyse des schweizerischen Energieverbrauchs 2000 bis 2015 nach Bestimmungsfaktoren, Bundesamt für Energie (BFE), 2016. http://www.bfe.admin.ch/php/modules/publikationen/stream.php?extlang=de\&name=de_399 764299.pdf.

[56] J. Luo, Z. Luo, J. Xie, D. Xia, W. Huang, H. Shao, W. Xiang, J. Rohn, Investigation of shallow geothermal potentials for different types of ground source heat pump systems (GSHP) of Wuhan city in China, Renew. Energy. 118 (2018) 230-244. doi:10.1016/j.renene.2017.11.017.

[57] W. Dönni, Fliessgewässertyp und thermisches Habitat der Fische: Evaluation des methodischen Vorgehens, Bundesamt für Umwelt (BAFU), 2016.

[58] X. Chen, H.-Z. Lin, G. Zhang, Effects of water depth and surface wind for lake water heat pump systems, Renew. Energy Resour. 31 (2013) 107-111.

[59] M. Pfaundler, T. Wüthrich, Saisonalität hydrologischer Extreme. Das zeitliche Auftreten von Hoch- und Niederwasser in der Schweiz, Wasser Energ. Luft. (2006) 77-82.

[60] N. Madden, A. Lewis, M. Davis, Thermal effluent from the power sector: An analysis of oncethrough cooling system impacts on surface water temperature, Environ. Res. Lett. 8 (2013) 035006. doi:10.1088/1748-9326/8/3/035006.

[61] K. Eisenack, Institutional adaptation to cooling water scarcity for thermoelectric power generation under global warming, Ecol. Econ. 124 (2016) 153-163. doi:10.1016/j.ecolecon.2016.01.016.

[62] S.N. Kazi, Fouling and fouling mitigation on heat exchanger surfaces, INTECH Open Access Publisher, 2012. http://cdn.intechopen.com/pdfs-wm/30778.pdf.

[63] A. Wacker, E. Von Elert, Settlement pattern of the zebra mussel, Dreissena polymorpha, as a function of depth in Lake Constance, Arch. Für Hydrobiol. 158 (2003) 289-301. doi:10.1127/0003-9136/2003/0158-0289.

[64] C.W. Ramcharan, D.K. Padilla, S.I. Dodson, Models to predict potential occurrence and density of the zebra mussel, Dreissena polymorpha, Can. J. Fish. Aquat. Sci. 49 (1992) 2611-2620. doi:10.1139/f92-289.

[65] D.G. MacDonald, Enhanced surface cooling as an alternative for thermal discharges, J. Environ. Eng. 135 (2009) 1326-1337. doi:10.1061/(ASCE)EE.1943-7870.0000090.

[66] J. Prats, R. Val, J. Armengol, J. Dolz, Temporal variability in the thermal regime of the lower Ebro River (Spain) and alteration due to anthropogenic factors, J. Hydrol. 387 (2010) 105-118. doi:10.1016/j.jhydrol.2010.04.002. 
[67] S.G. Manjunatha, K.B. Bobade, M.D. Kudale, Pre-cooling technique for a thermal discharge from the coastal thermal power plant, Procedia Eng. 116 (2015) 358-365. doi:10.1016/j.proeng.2015.08.299.

[68] IPCC, Climate Change 2014: Synthesis Report. Contribution of Working Groups I, II and III to the Fifth Assessment Report of the Intergovernmental Panel on Climate Change [Core Writing Team, R.K. Pachauri and L.A. Meyer (eds.)], IPCC, Geneva, Switzerland, 2014. https://epic.awi.de/37530/.

[69] J.C. Quijano, P.R. Jackson, S. Santacruz, V.M. Morales, M.H. García, Implications of Climate Change on the Heat Budget of Lentic Systems Used for Power Station Cooling: Case Study Clinton Lake, Illinois, Environ. Sci. Technol. 50 (2016) 478-488. doi:10.1021/acs.est.5b04094. 
- Waterbodies can be used as renewable energy sources for heating and cooling.

- The potential of the main lakes and rivers of Switzerland is estimated.

- The potential exceeds expected demands in most parts of the country.

- Modelling shows that temperature impacts in the waterbodies are weak.

- The presented methodology is readily applicable in many regions of the world. 